\title{
Responsiveness of the Federal Individual Income Tax to Changes in Income
}

THE YIELD OF THE FEDERAL INDIVIDUAL income tax increased from $\$ 55.4$ billion in fiscal year 1966 to an estimated \$103.3 billion in fiscal year 1973 . This is an increase of $\$ 47.9$ billion over a period during which personal income from production-henceforth to be identified as adjusted personal income-rose $\$ 357.2$ billion, ${ }^{1}$ suggesting a marginal rate on the increased income-or built-in flexibility - of about 13.5 percent. The built-in flexibility so computed is only the roughest of approximations, since it does not allow for the changes in the tax structure that took place during the period. Although tax rates were the same at the beginning and the end of the period, a number of major structural changes that affect revenues in both directions were enacted in 1969 and $1971 .^{2}$ The purpose of this paper is to measure the

Note: The work on this paper was supported by a grant from the RANN Program of the National Science Foundation. I am indebted to Robert E. Litan for his assistance in the regression analysis, to Catherine Armington for programming the simulation exercises on the tax file, and to Nancy Teeters for the use of her individual income tax data bank.

1. Personal income from production is personal income less transfer payments plus personal contributions for social insurance. The increase is measured from calendar year 1965 to calendar year 1972, since fiscal year receipts depend primarily on income in the previous calendar year.

2. The most important changes were increases in the per capita exemption and the percentage standard deduction, the introduction of a new low-income allowance, an increase in the maximum tax rate on capital gains from 25 to 35 percent, a new 10 percent tax on tax preferences, and a maximum marginal tax rate of 50 percent for earned income. 
built-in flexibility of the federal individual income tax as it applies to incomes received in 1973 and later years.

In the past, measures of the built-in flexibility of the income tax have been estimated from regressions based on time series data, using various statistical techniques to correct for the effect of changes in the tax law. ${ }^{3}$ It is now possible to make such estimates, through simulation, on the basis of the Internal Revenue Service tax file, which contains the income and tax information for a random, stratified sample of federal individual income tax returns. ${ }^{4}$ The calculations based on the tax file have two advantages: first, they automatically reflect the effect of changes in the distribution of taxable income that occur when incomes change; and, second, they can take into account the effects of changes in the tax law with a relatively high degree of accuracy. In this paper, the 1970 tax file is used to prepare estimates of the built-in flexibility of the income tax under conditions of sustained growth and during periods of cyclical instability, and these estimates are compared with those based on the time series analysis.

\section{Structure of the Income Tax}

The features of the income tax structure that have a significant bearing on its revenue yield are (1) the definition of income for tax purposes, (2) the allowable personal deductions, (3) the personal exemptions, and (4) the tax rates. Detailed data for each of these features, which are available annually from U.S. Internal Revenue Service, Statistics of Income, are shown in Appendix Table A-1 for the period 1947 through 1971; they are summarized in Table 1.

3. See, for example, Joseph A. Pechman, "Yield of the Individual Income Tax during a Recession," in Policies to Combat Depression, A Conference of the UniversitiesNational Bureau Committee for Economic Research (Princeton University Press for the National Bureau of Economic Research, 1956), pp. 123-45; E. Cary Brown and Richard J. Kruizenga, "Income Sensitivity of a Simple Personal Income Tax," Review of Economics and Statistics, Vol. 41 (August 1959), pp. 260-69; and William H. Waldorf, "The Responsiveness of Federal Personal Income Taxes to Income Change," Survey of Current Business, Vol. 47 (December 1967), pp. 32-45.

4. For a detailed description of the tax file and its uses, see Joseph A. Pechman, "A New Tax Model for Revenue Estimating," in Alan T. Peacock and Gerald Hauser (eds.), Government Finance and Economic Development (Paris: Organisation for Economic Co-operation and Development, 1965), pp. 231-44 (Brookings Reprint 102). The full sample contains over 90,000 returns, but for the calculations in this paper a subsample of 10,000 returns was adequate. The differences in the estimates based on several experimental runs of the full sample were negligible. 
Table 1. Selected Features of the Federal Individual Income Tax Structure, 1947-71

\begin{tabular}{|c|c|c|c|c|c|c|}
\hline Year & $\begin{array}{c}\text { Adjusted } \\
\text { gross in- } \\
\text { come as a } \\
\text { percent of } \\
\text { adjusted } \\
\text { personal } \\
\text { income }^{\mathrm{a}}\end{array}$ & $\begin{array}{l}\text { Percent of } \\
\text { adjusted } \\
\text { gross in- } \\
\text { come not } \\
\text { reported } \\
\text { on tax } \\
\text { returns }\end{array}$ & $\begin{array}{l}\text { Personal } \\
\text { deductions } \\
\text { as a percent } \\
\text { of adjusted } \\
\text { gross in- } \\
\text { come re- } \\
\text { ported on } \\
\text { tax returns }\end{array}$ & $\begin{array}{l}\text { Average } \\
\text { value of } \\
\text { personal } \\
\text { exemptions } \\
\text { (dollars) }\end{array}$ & $\begin{array}{c}\text { Taxable } \\
\text { income as a } \\
\text { percent of } \\
\text { adjusted } \\
\text { personal } \\
\text { income }\end{array}$ & $\begin{array}{c}\text { Average } \\
\text { effective } \\
\text { rate of tax } \\
\text { on taxable } \\
\text { income } \\
\text { (percent) }\end{array}$ \\
\hline 1947 & 94.5 & 12.9 & 11.8 & 539 & 41.5 & 24.0 \\
\hline 1948 & 92.0 & 11.7 & 11.9 & 647 & 37.1 & 20.6 \\
\hline 1949 & 92.9 & 12.3 & 12.4 & 648 & 36.3 & 20.2 \\
\hline 1950 & 93.5 & 11.1 & 12.2 & 649 & 39.1 & 21.8 \\
\hline 1951 & 92.3 & 11.2 & 12.5 & 650 & 40.2 & 24.4 \\
\hline 1952 & 91.4 & 10.6 & 12.7 & 651 & 40.7 & 25.9 \\
\hline 1953 & 91.5 & 10.3 & 13.0 & 651 & 41.0 & 25.7 \\
\hline 1954 & 90.6 & 9.4 & 13.4 & 652 & 41.3 & 23.2 \\
\hline 1955 & 91.4 & 9.1 & 13.5 & 653 & 42.8 & 23.1 \\
\hline 1956 & 91.6 & 8.9 & 13.6 & 653 & 44.1 & 23.1 \\
\hline 1957 & 91.0 & 8.5 & 14.1 & 654 & 44.4 & 23.0 \\
\hline 1958 & 90.6 & 9.6 & 14.5 & 654 & 43.5 & 23.0 \\
\hline 1959 & 91.2 & 8.5 & 14.9 & 655 & 45.6 & 23.2 \\
\hline 1960 & 90.5 & 8.8 & 15.3 & 655 & 44.9 & 23.0 \\
\hline 1961 & 91.0 & 8.2 & 15.6 & 656 & 46.0 & 23.2 \\
\hline 1962 & 90.4 & 8.3 & 15.7 & 656 & 46.4 & 23.0 \\
\hline 1963 & 90.3 & 7.8 & 16.1 & 656 & 47.2 & 23.1 \\
\hline 1964 & 90.9 & 8.1 & 16.9 & 657 & 48.5 & 20.5 \\
\hline 1965 & 90.9 & 8.1 & 16.6 & 657 & 49.7 & 19.4 \\
\hline 1966 & 90.9 & 8.4 & 16.3 & 657 & 50.9 & 19.6 \\
\hline 1967 & 91.2 & 7.7 & 16.2 & 658 & 52.5 & 20.0 \\
\hline 1968 & 91.6 & 7.4 & 16.5 & 658 & 53.9 & $20.3^{c}$ \\
\hline 1969 & 90.7 & 6.8 & 16.9 & 659 & 54.5 & $20.3^{\mathrm{o}}$ \\
\hline 1970 & 89.6 & 6.9 & 19.1 & 687 & 53.0 & $20.4^{\mathrm{c}}$ \\
\hline 1971 & 90.0 & 6.6 & 20.7 & 742 & 51.6 & 20.6 \\
\hline
\end{tabular}

Source: Appendix Table A-1.

a. Adjusted personal income is personal income less transfer payments plus personal contributions for social insurance.

b. Does not include special exemption for blindness.

c. Excludes surcharge.

The relationship between the amount of income reported for tax purposes-called adjusted gross income under the federal income tax-and adjusted personal income as measured by the Department of Commerce has been remarkably consistent over the years. Between 1947 and 1954, 
adjusted gross income declined from 94.5 percent to 90.6 percent of adjusted personal income; thereafter, it moved erratically between 89.6 and 91.6 percent. These movements were due partly to the volatility of capital gains, which are included in adjusted gross income but are excluded from adjusted personal income, and partly to the difficulties of correcting for the differences between the two concepts. ${ }^{5}$

Since not all income recipients are required to file tax returns and not everybody reports his income accurately, adjusted gross income reported on tax returns is lower than the aggregate for all recipients. However, the gap has been declining over the years, as incomes have grown and more and more people have moved above the minimum filing requirements. ${ }^{6}$ In $1947,12.9$ percent of total adjusted gross income was not reported on tax returns; by 1971 the percentage was down to 6.6 percent. $^{7}$

Between 1947 and 1971, the personal deductions reported on all tax returns rose from 11.8 percent to 20.7 percent of adjusted gross income. There were only relatively minor statutory changes in the allowable deductions between 1947 and 1963, but the ratio of personal deductions to income rose sharply in that period mainly because of the tremendous increases in itemized deductions associated with the broadened incidence of home ownership. Further increases in the ratio of personal deductions to income occurred in 1964, when the minimum standard deduction was enacted; in 1970, when the minimum standard deduction was supplemented by a low-income allowance; and in 1971, when a flat low-income allowance replaced the minimum standard deduction and the percentage standard deduction was raised. ${ }^{8}$

5. A detailed reconciliation between personal income and adjusted gross income is prepared periodically by the Bureau of Economic Analysis of the U.S. Department of Commerce. The last published estimates are given in "The Relationship between Personal Income and Taxable Income," Survey of Current Business, Vol. 50 (May 1970), pp. 19-21. I am grateful to the Bureau of Economic Analysis for making available to me its most recent revised estimates.

6 . Even though their incomes are below the filing requirements, many income recipients file returns to obtain refunds.

7. This suggests that the amount of underreporting is quite moderate. It is probably no more than half the adjusted gross income not reported on tax returns, or less than 3.5 percent.

8. The percentage standard deduction, which was enacted in 1944 , was originally 10 percent of income up to a maximum of $\$ 1,000$. It was raised to 13 percent with a maximum of $\$ 1,500$ in 1971 and to 15 percent with a maximum of $\$ 2,000$ for 1972 and later years. The minimum standard deduction, which was introduced in 1964, began at $\$ 200$ plus $\$ 100$ for each exemption. For 1970 , the minimum standard deduction was supple- 
The personal exemption was $\$ 500$ per capita in 1947 ; it was raised to $\$ 600$ in 1948 and remained at that level until it was raised to $\$ 625$ for 1970 , $\$ 675$ for 1971, and $\$ 750$ for 1972 and later years. Beginning in 1948, an extra exemption was given to taxpayers and their spouses who are 65 years of age or older or blind. The value of the exemptions per person in the population crept up between 1947 and 1969, the period when the statutory exemptions remained unchanged, because the proportion of aged persons in the population increased. Larger increases occurred in 1948, 1970, and 1971, when the per capita exemption was increased.

Although the statutory increases in personal deductions and exemptions have taken large chunks out of the tax base from time to time, taxable income has increased substantially in relation to adjusted personal income. Since 1947, the ratio has actually declined in years when the statutory exemptions or deductions were raised $(1948,1970$, and 1971) or in years of recession (1949 and 1958); in all other years except 1960, the ratio moved up-sometimes sharply - as more and more taxpayers crossed the taxable income threshold. As a result, taxable income on all returns rose from 41.5 percent of adjusted personal income in 1947 to a peak of 54.5 percent in 1969, and then declined to 53.0 percent in 1970 and 51.6 percent in 1971.

The tax rates, which are graduated by a bracket system, have been changed ten times since $1947 . .^{9}$ Aside from variations in the rates themselves, three significant structural changes that affected the progressivity of the income tax were made during this period: First, in 1948, the introduction of income splitting in effect doubled the width of the taxable income brackets for married couples. ${ }^{10}$ Second, in 1964, the first taxable income bracket, zero to $\$ 2,000$, was split into four $\$ 500$ brackets. Third, in 1969 , a special rate schedule was enacted for single persons who are not heads of households to limit their tax to no more than 20 percent above the

mented by the low-income allowance which varied with the number of exemptions and the size of income; together, the minimum standard deduction and the low-income allowance were limited to a maximum of $\$ 1,100$. In 1971 , the minimum standard deduction was removed and the low-income allowance was converted to a flat $\$ 1,050$ for 1971 and $\$ 1,300$ for 1972 and later years.

9. Changes in rates were made in 1948, 1950, 1951, 1952, 1954, 1964, and 1965. In addition, surcharges of 7.5 percent in 1968, 10 percent in 1969, and 2.5 percent in 1970 were applied to taxable income brackets above $\$ 1,000$.

10. In 1951, a separate rate schedule was adopted for heads of households to give them approximately half the advantage of income splitting. The revenue effect of this change is minor. 
tax paid by married couples with the same taxable income. Mainly as a result of these changes, the average effective rates of tax have varied from a low of 19.4 percent in 1965 to a high of 25.9 percent in 1952 (Table 1, last column). Perhaps the most interesting feature of the series on effective rates is that, despite the rise in incomes during the period 1954-63 when the tax rates remained unchanged, the average effective rate was virtually constant. By contrast, between 1965 and 1971, when the rates (exclusive of surcharge) also remained unchanged, the effective rate rose by an average of 0.2 percentage point per year. ${ }^{11}$

\section{Built-in Flexibility Based on Historical Data}

Despite the numerous changes that have taken place in the structure of the income tax in the last twenty-five years, an attempt to infer the built-in flexibility of the income tax from the historical record is not a hopeless exercise. Brown and Kruizenga developed a relatively simple formula to estimate the individual income tax base from aggregate data for the period 1929-53, and Waldorf later applied the same formula to data for 1947-65 with considerable success. ${ }^{12}$ To estimate tax liabilities, Waldorf added a rate variable to his equation, but he did not succeed in capturing the effect of changes in the rate of graduation when the schedule of tax rates changed. As will soon be noted, additional years of data have made it possible to estimate tax liabilities as well as taxable income from past data.

The Brown-Kruizenga formula is based on the hypothesis that the fraction of personal income that appears in the tax base varies directly with per capita income and inversely with per capita exemptions. Personal income includes many items that are not taxable (mainly transfer payments and fringe benefits) and excludes some that are taxable (mainly capital gains and employee payroll taxes). Consequently, adjusted personal income or estimated adjusted gross income is used for the per capita income variable. Exemptions are estimated from mid-year population figures, giving two exemptions for persons 65 years of age and over and one exemption for the

11. Throughout this paper, the effective rates are computed without regard to the surcharge that was in effect in 1968, 1969, and 1970. Since the basic rates were the same throughout the period, the rise in the average effective rate on taxable income from 1965 to 1971 was due entirely to the upward shift in the distribution of income.

12. Brown and Kruizenga, "Income Sensitivity of a Simple Personal Income Tax," and Waldorf, "Responsiveness of Federal Personal Income Taxes." 
remaining population. ${ }^{13}$ Although personal deductions are a major element in determining taxable income, they are too closely correlated with aggregate income to be used as an independent variable in estimating taxable income.

Since the tax base cannot exceed the total amount of income received by the entire population, it is appropriate to constrain the maximum ratio of taxable income to total income to unity. ${ }^{14}$ This is done by "explaining" the $\log$ of the proportion of total income that is not taxable rather than the portion that is taxable.

A description of the methods used to fit the Brown-Kruizenga formula to the 1947-71 data and of the experiments to improve on it are given in the appendix. The original formula-which related the log of the nontaxable portion of adjusted personal income to adjusted personal income per capita and exemptions per capita-held up well, but the results were improved somewhat by adding capital gains per capita as an additional independent variable. The final equation for taxable income is shown as equation (3) in the appendix.

To estimate tax liabilities, several departures were made from the technique Waldorf used for the earlier data. Waldorf expressed tax liabilities as a function of taxable income, the tax rate on the first $\$ 2,000$ of taxable income (the proxy variable for the entire rate structure), and dummy variables for the years in which the rates were altered. ${ }^{15}$ The drawback to this approach was that, since numerous changes were made in the tax law between 1947 and 1965, Waldorf found it necessary to include a large number of dummy variables relative to the number of data observations available. He was also handicapped in having only two observations-1964 and 1965 -to measure the effect of the Revenue Act of 1964.

Considerable experimentation identified three major changes in Waldorf's methods needed to estimate tax liabilities within a satisfactory margin of error. First, the period of estimation was shortened from 1947-71 to 1954-71 to avoid the use of dummy variables for the different tax rate

13. The number of blind people is small, so the special exemption for blindness is ignored.

14. It is conceivable that income subject to tax could exceed personal income. However, the portion of personal income that is not taxable greatly exceeds the taxable items that are excluded. Brown and Kruizenga experimented with higher and lower constraints, but concluded that unity is the most satisfactory ratio.

15. For a more complete description of Waldorf's estimating procedure, and the techniques used to update his results, see the appendix. 
schedules between 1947 and $1953 .{ }^{16}$ Second, a new variable was used to represent the various tax rate schedules. In place of the tax rate applying to the first $\$ 2,000$ of taxable income, an average tax rate was computed by weighting the actual rates for a particular year by the taxable income in each bracket in $1967 .{ }^{17}$ Third, another taxable income variable, assuming the value of zero prior to 1964, was introduced to account for the rise in the average effective tax rate on taxable income over the 1965-71 period. As indicated earlier, the effective rate was surprisingly constant during the 1954-63 years, but began a gradual upward climb beginning in 1965, when the Revenue Act of 1964 became fully effective. The rise in the average effective rate between 1965 and 1971 was certainly due to the accelerated upward movement in the distribution of income by rate classes, induced by the sustained and significant rise in personal incomes over these years. This hypothesis was confirmed by the high degree of statistical significance attached to the coefficient on this additional taxable income variable. Moreover, the final tax liabilities equation (equation 6 in the appendix) yielded an extremely close fit and very low residuals, as can be observed in Table A-2 of the appendix.

Table 2 summarizes estimates, based on equations (3) and (6), of the responsiveness of the income tax to changes in income for the years 1954-71 by two different measures. The first is built-in flexibility, which measures the absolute increase (decrease) in tax liabilities for every dollar increase (decrease) in adjusted personal income. The second is elasticity, which measures the percentage change in tax liabilities when adjusted personal income rises by 1 percent. The built-in flexibility measure is useful in evaluating the stabilizing effect of the income tax in terms of absolute changes in income; if the analysis is in terms of percentage change, elasticity is more useful. ${ }^{18}$

The first column of Table 2 shows estimates of the built-in flexibility of the tax base with respect to adjusted personal income. These figures tell a familiar story: except for 1970 and 1971, when exemptions were increased, a larger and larger percentage of the annual increment in income was in-

16. Coupled with the other modifications, this change in the data period resulted in the presence of only one dummy, for the 1954-63 years, in the final equation.

17. The use of 1967 for weighting purposes is arbitrary. The only requirements were that the year should represent the post-1964 tax brackets and that it should not be a terminal year.

18. The two measures are related. Elasticity may be obtained by dividing built-in flexibility by the average tax rate on personal income. 
Table 2. Built-in Flexibility and Elasticity of the Federal Individual Income Tax, by Selected Tax and Income Measures, 1954-71

\begin{tabular}{|c|c|c|c|c|c|c|}
\hline \multirow[b]{2}{*}{ Year } & \multicolumn{3}{|c|}{ Built-in flexibility } & \multicolumn{3}{|c|}{ Elasticity } \\
\hline & $\begin{array}{l}\text { Taxable } \\
\text { income to } \\
\text { adjusted } \\
\text { personal } \\
\text { income }^{\mathrm{c}} \\
\quad(1)\end{array}$ & $\begin{array}{l}\text { Tax } \\
\text { liabilities } \\
\text { to taxable } \\
\text { income } \\
\text { (2) }\end{array}$ & $\begin{array}{c}\text { Tax } \\
\text { liabilities } \\
\text { to adjusted } \\
\text { personal } \\
\text { income }^{\mathrm{c}} \\
(3)\end{array}$ & $\begin{array}{l}\text { Taxable } \\
\text { income with } \\
\text { respect to } \\
\text { adjusted } \\
\text { personal } \\
\text { income } \\
\text { (4) }\end{array}$ & $\begin{array}{c}\text { Tax } \\
\text { liabilities } \\
\text { with respect } \\
\text { to taxable } \\
\text { income } \\
\text { (5) }\end{array}$ & $\begin{array}{c}\text { Tax } \\
\text { liabilities } \\
\text { with respect } \\
\text { to adjusted } \\
\text { personal } \\
\text { income }^{\mathrm{c}} \\
(0)\end{array}$ \\
\hline 1954 & 0.589 & 0.230 & 0.136 & 1.42 & 1.00 & 1.42 \\
\hline $\begin{array}{l}1955 \\
1956 \\
1957 \\
1958 \\
1959\end{array}$ & $\begin{array}{l}0.599 \\
0.605 \\
0.605 \\
0.607 \\
0.616\end{array}$ & $\begin{array}{l}0.230 \\
0.230 \\
0.230 \\
0.230 \\
0.230\end{array}$ & $\begin{array}{l}0.138 \\
0.139 \\
0.139 \\
0.139 \\
0.141\end{array}$ & $\begin{array}{l}1.39 \\
1.38 \\
1.38 \\
1.38 \\
1.36\end{array}$ & $\begin{array}{l}1.00 \\
1.00 \\
1.00 \\
1.00 \\
1.00\end{array}$ & $\begin{array}{l}1.39 \\
1.38 \\
1.38 \\
1.38 \\
1.36\end{array}$ \\
\hline $\begin{array}{l}1960 \\
1961 \\
1962 \\
1963 \\
1964\end{array}$ & $\begin{array}{l}0.617 \\
0.623 \\
0.625 \\
0.630 \\
0.638\end{array}$ & $\begin{array}{l}0.230 \\
0.230 \\
0.229 \\
0.229 \\
0.238\end{array}$ & $\begin{array}{l}0.142 \\
0.143 \\
0.143 \\
0.144 \\
0.152\end{array}$ & $\begin{array}{l}1.35 \\
1.34 \\
1.34 \\
1.33 \\
1.32\end{array}$ & $\begin{array}{l}1.00 \\
1.00 \\
1.00 \\
1.00 \\
1.12\end{array}$ & $\begin{array}{l}1.35 \\
1.34 \\
1.34 \\
1.33 \\
1.48\end{array}$ \\
\hline $\begin{array}{l}1965 \\
1966 \\
1967 \\
1968 \\
1969\end{array}$ & $\begin{array}{l}0.647 \\
0.655 \\
0.664 \\
0.674 \\
0.679\end{array}$ & $\begin{array}{l}0.224 \\
0.227 \\
0.230 \\
0.233^{\mathrm{d}} \\
0.236^{\mathrm{d}}\end{array}$ & $\begin{array}{l}0.145 \\
0.149 \\
0.152 \\
0.157^{\mathrm{d}} \\
0.160^{\mathrm{d}}\end{array}$ & $\begin{array}{l}1.30 \\
1.29 \\
1.27 \\
1.26 \\
1.25\end{array}$ & $\begin{array}{l}1.12 \\
1.12 \\
1.12 \\
1.12^{\mathrm{d}} \\
1.12^{\mathrm{d}}\end{array}$ & $\begin{array}{l}1.46 \\
1.44 \\
1.43 \\
1.41^{\mathrm{d}} \\
1.40^{\mathrm{d}}\end{array}$ \\
\hline $\begin{array}{l}1970 \\
1971\end{array}$ & $\begin{array}{l}0.665 \\
0.664\end{array}$ & $\begin{array}{l}0.237^{d} \\
0.238\end{array}$ & $\begin{array}{l}0.158^{\mathrm{d}} \\
0.158\end{array}$ & $\begin{array}{l}1.27 \\
1.27\end{array}$ & $\begin{array}{l}1.12^{\mathrm{d}} \\
1.12\end{array}$ & $\begin{array}{l}1.43^{\mathrm{d}} \\
1.43\end{array}$ \\
\hline
\end{tabular}

Sources: Columns (1) and (4) are developed from appendix equation (3) and columns (2) and (5) from equation $(6)$; column $(3)=(1) \times(2)$; column $(6)=(4) \times(5)$. The calculations are made from data before rounding.

a. Built-in flexibility is the ratio of the absolute increase (decrease) in tax liabilities to the absolute increase (decrease) in adjusted personal income.

b. Elasticity is the ratio of the percentage change in tax liabilities to the percentage change in adjusted personal income.

c. Adjusted personal income is personal income less transfer payments plus personal contributions for social insurance.

d. Tax liabilities exclude surcharge in 1968-70.

cluded in taxable income. By 1971, about two-thirds of the increase in adjusted personal income was subject to tax. The second column shows the remarkably constant marginal tax rate on taxable income for the period 1954-63, and the subsequent upward drift in the marginal rate from the second taxable income variable which was added to the tax liabilities equation to capture the post-1964 developments. The marginal rate on taxable income rose when the Revenue Act of 1964 was enacted, but then declined 
the following year. A possible explanation for this phenomenon is that, in 1964, the effect of the large upward movement in income and the four-way split of the bottom bracket more than offset the effect of the rate reductions. Only in 1965, with the split first bracket already in effect, could yet another set of rate reductions lower built-in flexibility. The rise thereafter is an indication that-unlike the experience in 1954-63-as incomes continued to increase, the marginal tax of those already taxable exceeded the marginal tax of those who became taxable for the first time. To generate estimates of the built-in flexibility of tax liabilities with respect to adjusted personal income, the first two columns of Table 2 need merely be multiplied together. According to these estimates, even though the tax rates had been reduced significantly, the individual income tax took nearly $\$ 1.6$ billion out of every $\$ 10$ billion increase in income at the end of the period, as compared with less than $\$ 1.4$ billion at the beginning.

The fourth column of Table 2 presents the elasticity of taxable income with respect to adjusted personal income. This elasticity declined from 1.42 to 1.25 as incomes rose between 1954 and 1969 , and then increased to 1.27 in 1970 and 1971 in response to the adoption of the low-income allowance and the increases in the statutory exemption. ${ }^{19}$ The elasticity of tax liabilities with respect to taxable income is shown in the fifth column of the table. For convenience, this elasticity is rounded from 0.995 (the value of the regression coefficient on taxable income in the second equation) to unity for the 1954-63 years. The second taxable income variable raised the elasticity value for the tax rate on taxable income to 1.12 for the 1964-71 period. The elasticity of tax liabilities with respect to adjusted personal income is the product of the elasticity estimates in the fourth and fifth columns, shown in the last column. Although this final elasticity varied between 1.33 and 1.48 over the years listed, it was almost the same at the end as at the beginning of the period.

\section{Projected Liabilities under Conditions of Sustained Growth}

Given the regressions derived from the 1954-71 data, it is now possible to project the revenue yield of the individual income tax in future years.

19. The low-income allowance and the higher exemptions reduced the average ratio of taxable income to personal income, but it probably did not change the marginal ratio significantly. Since the elasticity is the ratio of the marginal to the average ratio, the elasticity rises somewhat when the average ratio declines. 
The reliability of the projection depends heavily on whether the additional taxable income variable in the tax liability equation accurately represents the effect on tax liabilities of the shift that occurs in the absolute distribution of income when incomes change. To make this test, income tax liabilities were estimated for the period 1973-95 on the basis of simulations of the 1970 tax file and of projections based on the 1954-71 regressions, using the same assumptions regarding the growth of incomes and of population.

Both sets of long-term estimates begin with projections based on known income developments in 1972 and estimates for $1973 .{ }^{20}$ Thereafter, per capita adjusted personal income and per capita adjusted gross income were increased at constant annual rates of 4, 5, 6, 8, and 10 percent..$^{21}$ Population was assumed to increase at an annual rate of 1 percent throughout the period, but exemptions per capita and per tax return were kept at the 1971 levels.

In making projections on the tax file, several additional assumptions were necessary to simulate the relationship between the growth in total income per capita and the tax liabilities on individual returns. First, adjusted gross incomes on all tax returns were increased proportionately beginning in 1973, on the assumption that the Lorenz curve for the distribution of income would remain unchanged..$^{22}$ Second, itemized deductions on returns that used them were assumed to have an elasticity of 1.05 with respect to income. ${ }^{23}$ Third, one out of four returns with standard deductions that were raised above the $\$ 10,000$ level in any year was switched to itemized deductions. The amount of deductions attributed to such returns was the

20. Adjusted personal income was obtained from the current estimates based on official national income accounts for 1972 and then raised 7.6 percent per capita in 1973. To reflect the movements in the stock market, realized capital gains were assumed to increase by 50 percent in 1972 and then to decline by 40 percent in 1973.

21. No distinction is made at this point between income growth due to growth of real income and income growth due to inflation. For the effect of inflation, see the section on inflationary conditions, below.

22. The effect of changes in the relative distribution of income that arise as a result of differential changes in the rate of growth of wages, capital gains, and other property income during periods of inflation is explored in the section on inflationary conditions.

23. This may well be too high for the future, since the ratio of deductions to income on itemized returns varied within a narrow range between 1964 and 1969, the most recent period during which there was no statutory change in deductions. (Statistics of Income-1964, Individual Income Tax Returns, Table M, p. 38, and Statistics of Income1969, Individual Income Tax Returns, Table 2.3, pp. 88,90.) Test runs indicate that even if the elasticity were raised to an unlikely 1.1 , the built-in flexibility estimates on the tax file would be virtually unaffected for 1975 and would be reduced by only about 0.006 in 1995. 
standard deduction plus 1 percent of the new adjusted gross income. ${ }^{24}$ Fourth, the number of tax returns filed was increased at the rate of 1.1 percent per year. This assumption was designed to expand the proportion of total income reported on tax returns as incomes grew, but to keep the relative distribution of income in the tax return population unchanged. ${ }^{25}$

Three major changes have been made in the income tax law since the end of 1971, when the historical data terminate-all of them effective for 1972 and later years. The per capita exemption was increased from $\$ 675$ to $\$ 750$; the percentage standard deduction was increased from 13 percent of income up to a maximum of $\$ 1,500$, to 15 percent of income up to a maximum of $\$ 2,000$; and the low-income allowance was raised from $\$ 1,050$ to $\$ 1,300$. The projections based on the tax file were easily programmed to accommodate these changes. The regressions based on the historical data include exemptions as an independent variable, but the effect of the personal deductions could not be measured because of their close correlation to aggregate income. Accordingly, the revised Waldorf equations based on the data for 1954-71 were used without any allowance for the 1972 changes in the personal deductions. ${ }^{26}$

To test the predictive ability of the tax file, an experiment was run to see whether it accurately "backcasted" the constant average tax rate on taxable

24. The proportion of returns above the $\$ 10,000$ income level using itemized deductions was already very high in 1970 -about 75 percent for returns with incomes of $\$ 10,000$ to $\$ 15,000$ and 91 percent for returns above $\$ 15,000$ (Statistics of Income-1970, Individual Income Tax Returns, Chart 2A, p. 102). Consequently, the estimates of built-in flexibility are not very sensitive to the assumption made with regard to those returns that switch from standard to itemized deductions. For example, if 75 percent of the returns with standard deductions going above $\$ 10,000$ but not above $\$ 15,000$ and 90 percent of those going above $\$ 15,000$ were given itemized deductions of 20 percent of their income, the built-in flexibility estimates for 1995 would be lowered by 0.008 ; elasticity would be virtually unaffected.

25. Despite the continued increase in the number of returns, the relative distribution of income reported on tax returns has not changed very much in recent years. This means that the distribution of the new entries into the taxpaying population is roughly the same as the distribution of those who leave it because of death, disability, or loss of income. Even if it is assumed that the extra 0.1 percent growth in the number of returns as compared with the population growth yielded only nontaxable returns (an extreme assumption), tax liability in 1995 is overestimated by only 2.2 percent.

26. These changes reduced tax liabilities by about 4 percent in 1972. See General Explanation of the Revenue Act of 1971, H.R. 10947, 92d Congress, Public Law 92-178, Prepared by the Staff of the Joint Committee on Internal Revenue Taxation (1972), pp. 14, 16. The dummy variable for 1970-71 in the taxable income equation incorporates some of the effect of the 1972 changes in the personal deductions, but there is no basis for judging how much. 
income for the period 1954-63. To make this test, the tax file was run for 1954, 1959, and 1963 using known values of adjusted personal income, capital gains, exemptions, and deductions from Statistics of Income, and assuming that the relative distribution of income and of capital gains was the same as in 1970 (the year of the tax file). As the following table shows, the tax file "predicts" the constant average rate of tax (before credits) on taxable income in 1954, 1959, and 1963 and approximates the Statistics of Income figures for each of the years remarkably well.

\section{Average effective individual income} tax rates before credits (percent)

\begin{tabular}{ccc}
\cline { 2 - 2 } Year & $\begin{array}{c}\text { From } \text { Statistics } \\
\text { of Income }\end{array}$ & From the tax file \\
1954 & 23.3 & 23.3 \\
1959 & 23.5 & 23.0 \\
1963 & 23.5 & 23.2
\end{tabular}

Considering the tremendous differences in the methodology of the two approaches, the 1973 estimates of taxable income and of tax liability from the regression equations and the tax file were close. The estimate of taxable income from the revised Waldorf equations was 1.2 percent higher than the estimate from the tax file ( $\$ 489$ billion vs. $\$ 483$ billion), the estimate of tax liability was 0.7 percent lower ( $\$ 102.7$ billion vs. $\$ 103.4$ billion), ${ }^{27}$ and the estimate of the effective rate of tax was 0.6 percentage point lower (21.0 percent vs. 21.6 percent). Thus, the two sets of long-term simulations begin at approximately the same levels for both taxable income and tax liabilities. ${ }^{28}$

Tables 3 and 4 and Figure 1 summarize the results of the long-term simulations for the period 1975-95. Tax liabilities grow at faster rates as the rate of income growth increases under both simulations, but the revised

27. The projection of tax liabilities on the tax file is for tax before credits. The credits amounted to $\$ 618$ million in 1971, the last year for which such data are available. (Preliminary Report, Statistics of Income-1971, Individual Income Tax Returns, p. 21.) The estimated difference of 0.6 percent assumes that the amount of the tax credits increased proportionately to adjusted personal income between 1971 and 1973.

28. The elasticity of tax with respect to adjusted personal income under the Waldorf equations was the same for 1973 as for 1971 , despite the fact that elasticity tends to decline over time if the tax law remains unchanged (see Table 2 for the periods 1954-63 and 1965-69). The elasticity held up because of the large increase in capital gains between 1971 and 1973. 
Table 3. Federal Individual Income Tax Liabilities, Built-in Flexibility, and Elasticities, Assuming 5 and 8 Percent Annual Rates of Growth of Per Capita Adjusted Personal Income, Based on the Revised Waldorf Equations and the 1970 Tax File Simulations, Selected Years, 1975-95

\begin{tabular}{|c|c|c|c|c|}
\hline \multirow[b]{2}{*}{ Year } & \multicolumn{2}{|c|}{$\begin{array}{l}5 \text { percent annual } \\
\text { growth rate }\end{array}$} & \multicolumn{2}{|c|}{$\begin{array}{l}8 \text { percent annual } \\
\text { growth rate }\end{array}$} \\
\hline & $\begin{array}{c}\text { Revised } \\
\text { Waldorf } \\
\text { equations }\end{array}$ & $\begin{array}{c}\text { Tax file } \\
\text { simulations }\end{array}$ & $\begin{array}{l}\text { Revised } \\
\text { Waldorf } \\
\text { equations }\end{array}$ & $\begin{array}{c}\text { Tax file } \\
\text { simulations }\end{array}$ \\
\hline \multicolumn{5}{|c|}{ Tax liabilities (billions of dollars) } \\
\hline 1975 & 121 & 125 & 131 & 136 \\
\hline 1980 & 181 & 193 & 237 & 263 \\
\hline 1985 & 268 & 298 & 421 & 500 \\
\hline 1990 & 393 & 458 & 737 & 937 \\
\hline 1995 & 574 & 699 & 1,273 & 1,697 \\
\hline \multicolumn{5}{|c|}{ Built-in flexibility } \\
\hline 1975 & 0.167 & 0.176 & 0.170 & 0.183 \\
\hline 1980 & 0.181 & 0.200 & 0.192 & 0.223 \\
\hline 1985 & 0.196 & 0.227 & 0.214 & 0.270 \\
\hline 1990 & 0.210 & 0.258 & 0.237 & 0.317 \\
\hline 1995 & 0.225 & 0.289 & 0.261 & 0.350 \\
\hline \multicolumn{5}{|c|}{ Elasticities $^{\mathrm{C}}$} \\
\hline 1975 & 1.41 & 1.54 & 1.40 & 1.58 \\
\hline 1980 & 1.37 & 1.51 & 1.35 & 1.53 \\
\hline 1985 & 1.34 & 1.49 & 1.31 & 1.50 \\
\hline 1990 & 1.32 & 1.48 & 1.28 & 1.45 \\
\hline 1995 & 1.29 & 1.45 & 1.25 & 1.35 \\
\hline
\end{tabular}

Sources: Projections for the revised Waldorf equations are based on equations ( 3 ) and ( 6 of the appendix. a. The tax file estimates assume no change in the relative distribution of income as income grows.

b. Built-in flexibility is the ratio of the absolute increase (decrease) in tax liabilities to the absolute increase (decrease) in adjusted personal income.

c. Elasticity is the ratio of the percentage change in tax liabilities to the percentage change in adjusted personal income.

Waldorf equations do not capture the full effect of the progressivity of the income tax and, therefore, greatly understate its responsiveness to income growth. For example, assuming a 5 percent growth in adjusted personal income per capita, the tax liabilities estimated from the tax file exceed those estimated from the equations by 3 percent in 1975, 11 percent in 1985, and 22 percent in 1995. The built-in flexibility and elasticity measures reflect these differences. By 1995, the tax file estimate of the built-in flexibility of the income tax is 0.289 as compared with only 0.225 for the estimates from the equations. Similarly, the tax file estimate of the elasticity of the income 
Table 4. Projections of Built-in Flexibility and Elasticities of the Federal Individual Income Tax at Selected Annual Rates of Growth of Per Capita Adjusted Personal Income, Based on Simulations from the 1970 Tax File, Selected Years, 1975-95

\begin{tabular}{cccccc}
\hline & \multicolumn{5}{c}{ Annual growth rates in income per capita } \\
\cline { 2 - 6 } Year & 4 percent & 5 percent & 6 percent & 8 percent & 10 percent \\
\hline \multicolumn{5}{c}{ Built-in flexibility } \\
1975 & 0.173 & 0.176 & 0.179 & 0.183 & 0.187 \\
1980 & 0.192 & 0.200 & 0.207 & 0.223 & 0.238 \\
1985 & 0.212 & 0.227 & 0.242 & 0.270 & 0.298 \\
1990 & 0.236 & 0.258 & 0.279 & 0.317 & 0.344 \\
1995 & 0.262 & 0.289 & 0.314 & 0.350 & 0.370 \\
& \multicolumn{5}{c}{ Elasticity } \\
1975 & 1.52 & 1.54 & 1.56 & 1.58 & 1.59 \\
1980 & 1.49 & 1.51 & 1.52 & 1.53 & 1.54 \\
1985 & 1.48 & 1.49 & 1.50 & 1.50 & 1.49 \\
1990 & 1.47 & 1.48 & 1.48 & 1.45 & 1.38 \\
1995 & 1.46 & 1.45 & 1.43 & 1.35 & 1.26 \\
\hline
\end{tabular}

a. The estimates assume no change in the relative distribution of income as income grows.

b. Built-in flexibility is the ratio of the absolute increase (decrease) in tax liabilities to the absolute increase (decrease) in adjusted personal income.

c. Elasticity is the ratio of the percentage change in tax liabilities to the percentage change in adjusted personal income.

$\operatorname{tax}$ in 1995 is 1.45 , while the equations yield an estimate of only 1.29 (Table 3). At an 8 percent growth rate, the differences are considerably larger for the built-in flexibility measure.

These comparisons do not by themselves prove that the estimates based on the tax file are more accurate than those obtained from the Waldorf equations. One clue is given by the separate estimates of the built-in flexibility of the tax base and of the average effective rates under the two approaches. Throughout the period, the estimates of the built-in flexibility of the tax base obtained from the Waldorf equations are somewhat higher than the estimates from the tax file. Consequently, somewhat more than the entire difference in tax liabilities is explained by the lower effective rate on taxable income obtained from the Waldorf equations. ${ }^{29}$ Since the tax file does not overestimate the growth in the tax base, it is fair to assume that its forecasts of the distribution of the tax base by rate brackets (which

29. For example, for the year 1980 , assuming a 5 percent annual growth rate, the built-in flexibility of the tax base is 0.698 from the Waldorf equations and 0.691 from the tax file. The marginal effective rates are 0.259 and 0.289 , respectively. 
Figure 1. Average Effective Federal Individual Income Tax Rates and Annual Rate of Growth of Tax Liabilities, at Selected Annual Rates of Growth in Per Capita Adjusted Personal Income, Based on Simulations from the 1970 Tax File, 1975-95
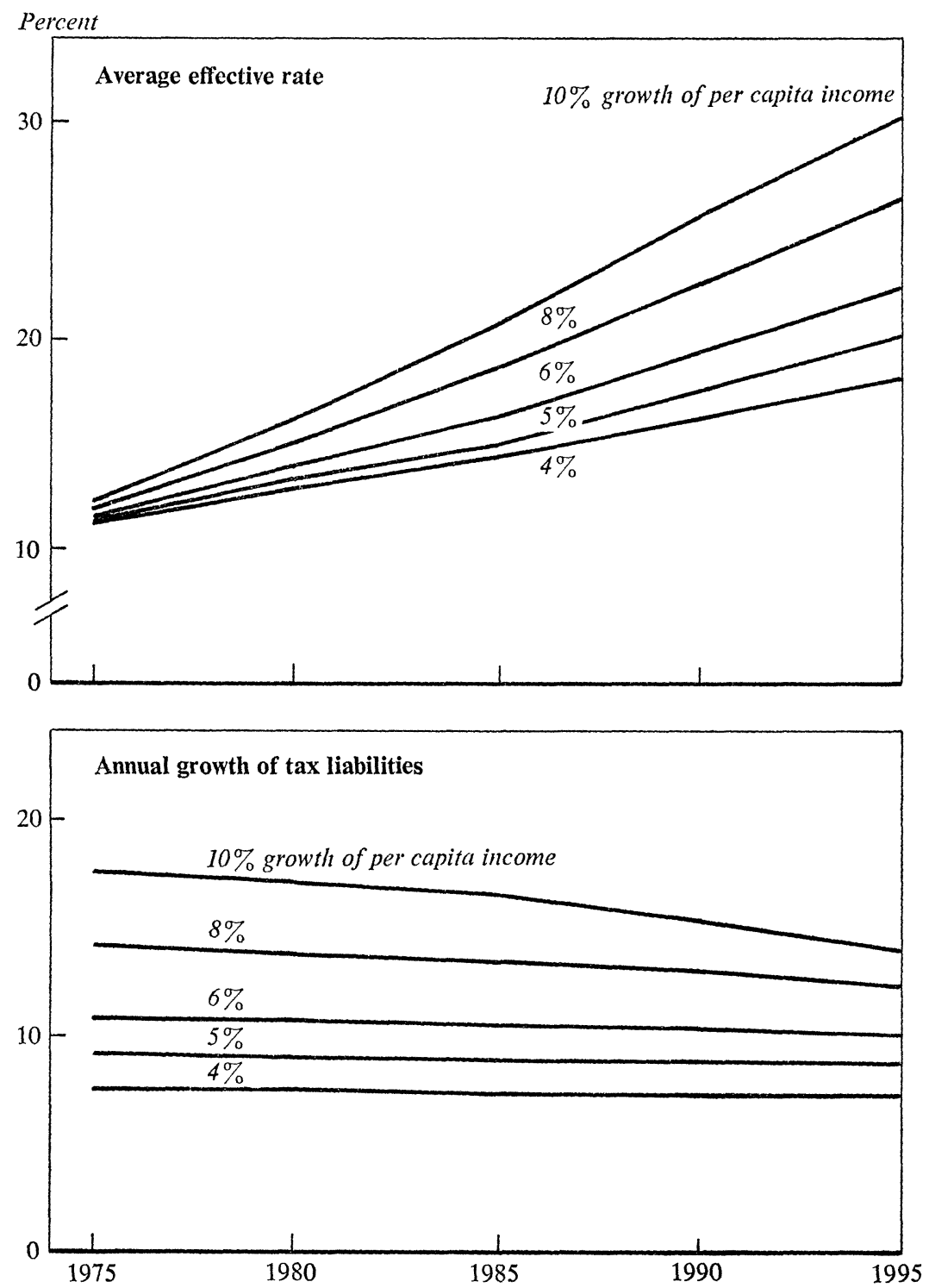

a. The estimates assume no change in the relative distribution of income as income grows. Simulations begin in the first quarter of 1974 . See text for the other assumptions used in preparing the estimates. 
determines the average effective tax rate on taxable income) are fairly accurate. ${ }^{30}$

On the assumption that the tax file estimates are more nearly correct, the following observations may be made about the responsiveness of the income tax under present law to changes in income in the years ahead:

1. The built-in flexibility of the income tax has increased significantly in recent years. In 1968, a year in which per capita adjusted personal income rose 8 percent, built-in flexibility was 0.157 (Table 2). Though exemptions and deductions have been liberalized in recent years, on the assumption of an 8 percent annual income growth rate, built-in flexibility would be 0.183 in 1975, 0.270 in 1985, and 0.350 in 1995 (Table 3). To put it in another way, the annual fiscal dividend or fiscal drag from the income tax would be almost twice as much in 1995 as in $\mathbf{1 9 7 5}$. The explanation of this development is that, with the continuous upward shift of incomes in the taxable income scale, the effect of rate graduation becomes more and more pronounced (see Figure 1). With continued increases in income, built-in flexibility would ultimately approach a weighted average of the top rates applying to various types of income, or about 50 percent. ${ }^{31}$

2. Assuming continuous growth of income per capita, individual income tax revenues will grow at an almost constant rate for a long time (Figure 1). For example, at a 5 percent growth rate, the annual revenue growth declines from 9.3 percent in 1975 only to 8.8 percent in 1995. At higher growth rates, which imply substantial rates of inflation, the decline in the rate is more noticeable, but revenue growth remains very large even at the end of twenty years. Thus, at an 8 percent annual growth rate, annual revenue growth is 14.3 percent in 1975 and it is still 12.3 percent in 1995. In dollar terms, the annual revenue growth increases from $\$ 11$ billion in 1975 to $\$ 56$ billion at a 5 percent growth rate and from $\$ 17$ billion to $\$ 185$ billion at an 8 percent growth rate.

3. The built-in stabilizing properties of the income tax are directly related to the growth rate. In 1975, the increase in tax revenue would cut into the increase in adjusted personal income by 17.3 percent at a growth rate of 4 percent, 17.9 percent at 6 percent, 18.3 percent at 8 percent, and 18.7 percent at 10 percent. If present law remains in effect, in 1995 the individ-

30. Assuming, of course, that the relative distribution of income remains unchanged.

31. This is an average, with 1971 weights, of the 50 percent top rate on earned incomes, 35 percent top rate on capital gains, 10 percent rate on preference incomes, and 70 percent rate on other property incomes. 
ual income tax will siphon off 26.2 percent of the increase in income at a growth rate of 4 percent, 31.4 percent at 6 percent, 35.0 percent at 8 percent, and 37.0 percent at 10 percent (Table 4).

4. In 1975 , the elasticity of the individual income tax will vary from 1.52 to 1.59 for annual growth rates in per capita income between 4 percent and 10 percent. Thereafter, the elasticity declines moderately for the lower growth rates and sharply for the higher growth rates (Table 4). This pattern reflects the fact that the largest percentage increase in taxes occurs when individual incomes increase from a low level. ${ }^{32}$

\section{Projected Liabilities under Conditions of Instability}

To illustrate the built-in flexibility of the individual income tax under conditions of instability, three sets of simulations were prepared on the basis of the 1970 tax file. These simulations trace the behavior of the income tax (1) during business cycles of varying lengths and severity; (2) during periods of inflation in which the relative distribution of adjusted personal income remains the same or changes radically; and (3) during periods in which the stock market produces sharp fluctuations in reported capital gains. The simulations are on a quarterly basis and begin with the first quarter of 1974, on the assumption that per capita adjusted personal income in that quarter is running at an annual rate that is 5 percent higher than the average for calendar year 1973. All the other assumptions used in the long-term simulations were carried over into the short-term simulations; any modifications served only to adapt them to a quarterly basis. ${ }^{33}$

\section{CYCLICAL CONDITIONS}

The business cycle simulations assume contractions of two and four quarters and uniform rates of decline in per capita adjusted personal in-

32. For example, when adjusted gross income increases 10 percent the tax of a married couple with two children increases 73 percent at $\$ 5,000$ and 17 percent at $\$ 50,000$. The calculation assumes personal deductions of 15 percent of adjusted gross income or the low-income allowance, whichever is higher.

33. Thus, it was assumed that population continues to grow by 1 percent a year and the number of income tax returns by 1.1 percent a year; that the elasticity of itemized deductions with respect to income is 1.05; and that one out of every four taxpayers switches from the standard deduction to itemized deductions when incomes rise above $\$ 10,000$. When incomes decline, returns with itemized deductions are switched to standard deduction if the standard deduction exceeds the itemized deductions calculated on the basis of the 1.05 elasticity. 
come and its components of 0.5 percent, 1 percent, and 2 percent per quarter. To complete the cycles, the expansions were allowed to run three times as long as the contractions and rates of growth in per capita incomes were selected to return to long-term trend values underlying the 5 percent growth rate calculations in Figure 1. This required rates of income growth of 1.81 percent, 1.98 percent, and 2.33 percent, respectively, for the three cycles. While no business cycle has ever exhibited these relatively simple characteristics, actual experience in the United States since the end of World War II has been well within the assumed patterns. ${ }^{34}$

The results of these simulations for the income tax laws applying to 1954, 1965, and 1973 are shown in Table 5. The first set of calculations shown in the table comprises the horizontal built-in flexibility and elasticities, which are calculated on the basis of incomes and tax liabilities at the previous peak or trough. These compare the reduction in tax liabilities between the peak and the trough of the cycle with the loss of income during the period of contraction. The second comprises the vertical built-in flexibility and elasticities, which are calculated on the basis of income and tax liabilities at the long-term growth trend values in the trough quarter of the contraction. These compare the shortfall in tax liabilities below their trend value at the trough of the cycle with the shortfall of income below trend at the trough.

The horizontal measures of the income sensitivity of the income tax cyclical conditions greatly exceed the corresponding measures in the longterm simulations, while the vertical measures are roughly of the same magnitude. For example, under the law that is now in effect, the horizontal built-in flexibility of the income tax in the mildest recessions shown in Table 5 (contractions at a rate of decline of 0.5 percent per quarter) is in the neighborhood of 0.24 compared with 0.17 or 0.18 for 1975 under conditions of sustained growth (see Table 4). Similarly, the horizontal elasticity in such a contraction is about 2.1 as compared with a long-term estimate of 1.5 for the year 1975 . The greater horizontal sensitivity of the income tax during periods of contraction reflects mainly the continued increase in the number of exemptions as incomes decline. In addition, the low-income allowance in effect places a floor under the personal deductions, even if it is assumed that itemized deductions have an elasticity with respect to in-

34. The longest contraction was for a period of four quarters, with declines in personal income per capita of less than 0.5 percent. Thus, the longest and severest contractions in these simulations would be regarded as a serious depression. 


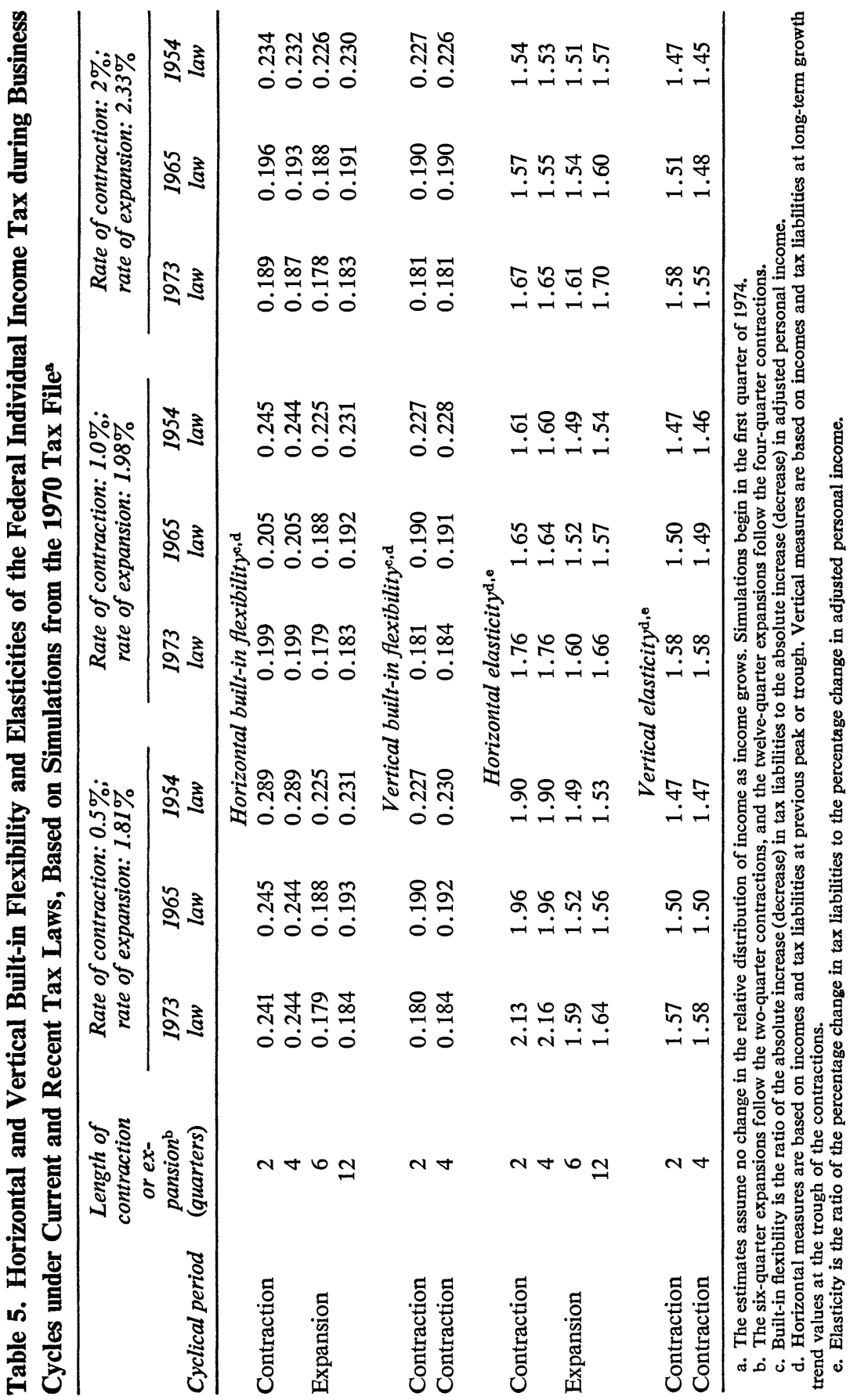


come that is greater than one. On the other hand, there is very little difference between the vertical and long-term measures, because the comparison is being made for the same quarter so that the number of exemptions are the same in both cases. Thus, the vertical built-in flexibility under present law is about 0.18 for the mildest recession shown in Table 5, as compared with trend values of between 0.17 and 0.18 for 1975 (Table 4). In other words, so long as population increases, the exemption feature will augment the stabilizing effectiveness of the income tax during a recession, but will dampen it over the longer run.

Another conclusion to be drawn from Table 5 is that changes in the tax law since 1954 have reduced the built-in flexibility, but increased the elasticity, of the income tax with respect to adjusted personal income during cyclical movements. The decline in built-in flexibility is due to the reductions in tax rates made in 1964 and the liberalizations of the exemptions and deductions under the 1969 and 1971 tax acts. Elasticity has increased because the splitting of the first $\$ 2,000$ bracket into four $\$ 500$ brackets, together with the higher exemptions and personal deductions, has enhanced progression.

\section{INFLATIONARY CONDITIONS}

Since the income tax applies to money income, its response to increases in money income during periods of inflation will differ from the responses already measured with the use of the tax file (see Figure 1) insofar as the inflation alters the distribution of income by source and by size. To illustrate such effects, a series of quarterly simulations were made on the tax file, again beginning in the first quarter of 1974, assuming increases in per capita adjusted personal income of 2,3 , and 4 percent per quarter for a period of two years. Income tax liabilities were first computed on the assumption that all incomes rise by the same percentage, thus keeping the relative distribution unchanged. To simulate a "profit inflation," per capita property and entrepreneurial incomes were raised by twice the average rate -that is, at 4, 6, and 8 percent per quarter-and wages and salaries were allowed to rise just enough to keep the weighted average increase in total income per capita at 2,3 , and 4 percent per quarter. ${ }^{35}$ This required in-

35. The calculations were based on the 1971 distribution of adjusted personal income between wages and salaries (including social security taxes) and other income. Capital gains, which are not included in adjusted personal income, were assumed to increase at the same rate as other income. The effect of differential capital gains changes is examined separately later. 
creases in per capita wage and salary income of 1.34, 2.02, and 2.69 percent per quarter. To simulate a "wage inflation," the assumptions were reversed. Per capita wages and salaries were increased by 10 percent more than the average rate-that is, by $2.2,3.3$, and 4.4 percent per quarter-while per capita property incomes were allowed to increase by only 1.39, 2.09, and 2.78 percent per quarter so that the increase in total income per capita would again average 2,3 , and 4 percent per quarter. The changes in the distribution of income implied by the simulation of the profit inflation are much larger than any two-year changes experienced in the United States since 1947, while the changes implied by the simulation of the wage inflation are similar in magnitude to the two-year changes actually observed in the same period. ${ }^{36}$

Because wages and salaries are roughly three-quarters of adjusted personal income, the built-in flexibility and the elasticity of the income tax are virtually the same in an inflation in which all incomes increase proportionately and in a wage inflation (Table 6). During a profit inflation of the magnitudes simulated in this series of calculations, the two measures are raised significantly. For example, after a year with 3 percent inflation per quarter, built-in flexibility is 0.186 if all incomes increase proportionately, but it increases to 0.200 if property and entrepreneurial incomes rise by twice the average rate. The corresponding figures for the elasticity of the income tax in these conditions are 1.62 and 1.73, respectively. But such changes are highly unlikely because the assumptions are unrealistic. For the range of recent experience in the United States, the built-in flexibility and elasticity of the income tax would be virtually unaffected by changes in the distribution of incomes that are included in adjusted personal income.

\section{THE EFFECT OF CAPITAL GAINS}

Between 1966 and 1971, year-to-year changes in the net capital gains reported on tax returns were +33 percent, +29 percent, -15 percent, -28

36. For example, after two years of increases in average money income of 3 percent per capita per quarter, wages and salaries decline from 75.3 percent to 70.5 percent of adjusted personal income in the profit inflation and rise to 77.1 percent of adjusted personal income in the wage inflation. Since 1947, wage and salary income as a percentage of adjusted personal income has changed by less than 1 percent in twenty-one years; and in only three years was the change between 1 and 1.5 percent. Economic Report of the President, January 1973, Table C-19, pp. 214-15. 
percent, and +36 percent. ${ }^{37}$ These fluctuations reflect the gyrations of the stock market, which if anything has moved inversely to the rate of change in the general price level in recent years. To evaluate the effect of such large changes in capital gains on income tax revenues, the simulations that assume 2, 3, and 4 percent quarterly rates of growth in per capita income were modified to allow for quarterly increases and decreases of 8 percent per capita in capital gains alone. All other income increases were kept the same. At a quarterly rate of 8 percent, per capita capital gains would rise by 36 percent or fall by 28 percent per year, percentages that are not very different from the year-to-year changes in four of the five years between 1966 and 1971.

The results of the capital gains simulations are also shown in Table 6. In all cases, the influence of capital gains on the income sensitivity of the income tax is large, at least as compared to the effects of the wage and profit inflations. For example, with quarterly growth of 2 percent per capita in all other kinds of income, a quarterly rise in capital gains of 8 percent per capita would increase the built-in flexibility of the income tax with respect to adjusted personal income from 0.182 to 0.200 in the first year and from 0.189 to 0.216 in the second year; a quarterly reduction of 8 percent would reduce built-in flexibility to 0.155 in the first year and 0.169 in the second. The changes in elasticity are of similar proportions. Thus, capital gains have a major influence on the cyclical sensitivity of the income tax and could have a perverse effect if stock market prices continued to move inversely to the general price level.

\section{REAL TRANSFERS TO THE GOVERNMENT DURING INFLATION}

The exercise summarized in Table 6 also permits a calculation of the automatic transfer of real resources from the taxpayers to the government during an inflation via the individual income tax. To make this calculation, it was assumed that per capita adjusted personal income and capital gains would grow at 4 percent a year in a noninflationary situation. ${ }^{38}$ Tax

37. These figures refer to the portion of net capital gains included in adjusted gross income. See Statistics of Income-1970, Individual Income Tax Returns, Table 82, p. 310, and Preliminary Report, Statistics of Income-1971, Individual Income Tax Returns, Table 3, p. 16.

38. This is the sum of 3 percent annual growth in per capita productivity and a minimum allowance of 1 percent for the gradual increase in the general price level that occurs during a noninflationary period. 


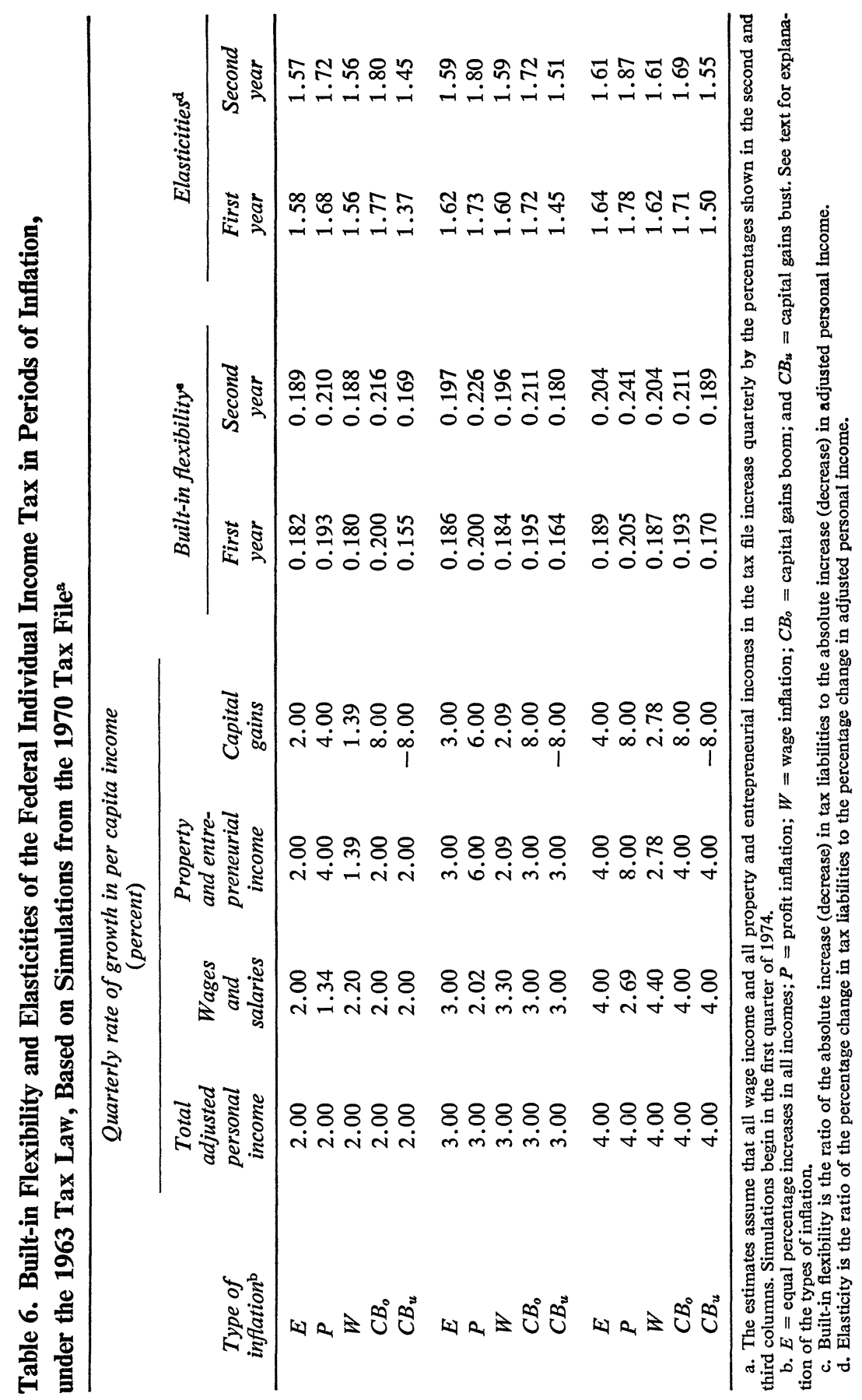


Table 7. Resource Transfer from Individual Income Taxpayers to the Federal Government after Eight Quarters of Inflation, Based on Simulations from the 1970 Tax Filea

\begin{tabular}{lcc}
\hline & \multicolumn{2}{c}{ Resources transferred } \\
\cline { 2 - 3 } $\begin{array}{c}\text { Per capita } \\
\text { (percent growth }\end{array}$ & $\begin{array}{c}\text { Percent of } \\
\text { disposable } \\
\text { income }\end{array}$ & $\begin{array}{c}\text { Percent of } \\
\text { tax liability }\end{array}$ \\
\hline 4 (noninflationary) & 0.0 & 0.0 \\
$8.2^{\circ}$ & 0.7 & 4.9 \\
$12.6^{\mathrm{d}}$ & 1.4 & 8.8 \\
$17.0^{\circ}$ & 2.1 & 12.9
\end{tabular}

a. The estimates assume that all incomes on the tax file increase by the percentages shown in the first column. Simulations begin in the first quarter of 1974 .

b. Amount of tax attributable to the application of the progressive rates to the portion of income that is due to inflation.

c. 2 percent per quarter.

d. 3 percent per quarter.

e. 4 percent per quarter.

liabilities and disposable incomes at the end of such a two-year period were calculated using the built-in flexibility estimates derived from the tax file for the year 1975 (see Table 4). The aggregate disposable income after a twoyear period of quarterly increases in per capita income of 2,3 , and 4 percent (that is, annual income increases of $8.2,12.6$, and 17.0 percent, respectively) were then compared with the amount of income that would be needed to maintain the real purchasing power of the disposable income in the noninflationary situation. The difference between the two represents the loss of income to taxpayers resulting from the presence of the progressive income tax, expressed at the inflated prices.

The transfer of resources defined in this way is not impressive (Table 7). For example, per capita income increases of 17 percent a year imply annual rates of inflation of 14 percent. ${ }^{39}$ Individual income tax liabilities at the end of two years of such an inflation are 12.9 percent higher than they would have been in the noninflationary situation, while disposable income is only 2.1 percent lower. ${ }^{40}$ If the exemptions and the tax brackets were adjusted to eliminate this real tax increase, the revenue lost could be recovered by

39. On the assumption that productivity growth accounts for 3 percent, the remaining 14 percent is due to inflation.

40. The degree of variation around this average is not very large. For a married couple with two children, the real transfer rises from about 2.5 percent of disposable income at the $\$ 5,000$ to $\$ 10,000$ level to a maximum of about 5.7 percent in the highest income level. 
Table 8. Comparison of Tax Liabilities after a Two-Year Inflation of $\mathbf{1 4}$ Percent a Year, under Present Law and Two Methods of Correcting for Inflation, Married Couples with Two Children, Selected Incomes

\begin{tabular}{|c|c|c|c|c|c|}
\hline \multirow{2}{*}{$\begin{array}{c}\text { Income } \\
\text { (dollars) }\end{array}$} & \multicolumn{3}{|c|}{ Tax liabilities (dollars) } & \multicolumn{2}{|c|}{$\begin{array}{c}\text { Percentage change from } \\
\text { tax liabilities under } \\
\text { present law }\end{array}$} \\
\hline & Present law ${ }^{\mathrm{b}}$ & Method $A^{\mathrm{o}}$ & Method $B^{\mathrm{d}}$ & Method $A^{\mathrm{o}}$ & Method $B^{\mathrm{d}}$ \\
\hline 5,000 & 98 & 0 & 0 & -100.0 & -100.0 \\
\hline 10,000 & 905 & 724 & 865 & -20.0 & -4.4 \\
\hline 15,000 & 1,765 & 1,524 & 1,793 & -13.6 & +1.6 \\
\hline 20,000 & 2,760 & 2,424 & 2,821 & -12.2 & +2.2 \\
\hline 25,000 & 3,890 & 3,428 & 3,951 & -11.9 & +1.6 \\
\hline 50,000 & 11,915 & 10,263 & 11,423 & -13.9 & -4.1 \\
\hline 100,000 & 34,500 & 31,026 & 33,462 & -10.1 & -3.0 \\
\hline
\end{tabular}

a. Tax liabilities computed on the assumption that taxpayer uses the low-income allowance of $\$ 1,300$ or 15 percent of income, whichever is higher.

b. Present law refers to the rates and exemptions applying to the year 1973.

c. Method $\mathbf{A}$ would increase the exemptions and the bracket limits by the percentage of inflation.

d. Method B would increase the exemptions and the bracket limits by the percentage of inflation and would raise the marginal tax rates by 3 percentage points.

increasing the tax rates by an average of 3.1 percentage points in each bracket. The reduction in real income and the necessary rate adjustments would be even smaller for the more moderate inflations.

The kind of adjustments in tax liabilities implied under a tax system that corrected for an inflation of 14 percent a year over a period of two years is illustrated in Table 8 for a family of four with selected incomes ranging from $\$ 5,000$ to $\$ 100,000$. In this table, the tax liabilities under present law are compared with those resulting from the application of two methods of correcting for inflation. Method A would increase the exemptions and the bracket limits by the percentage of inflation. This would completely remove the loss of income by taxpayers resulting from the application of the progressive income tax to the inflated incomes. ${ }^{41}$ Method $B$ is the same as method A, except that the marginal tax rates are increased by 3 percentage points across the board. The increase in rates is designed to recover the revenue lost as a result of the correction for inflation. Thus, method B raises the same amount of revenue as the present law, but distributes the

41. Canada is considering the adoption of such a system effective with incomes received in 1974. See John Bossons and Thomas A. Wilson, "Adjusting Tax Rates for Inflation,” Canadian Tax Journal, Vol. 21 (May-June 1973), pp. 185-99. 
inflation penalty approximately in proportion to the taxable incomes before the inflation.

If method A were used, the tax would be reduced by 100 percent at the $\$ 5,000$ income level, by 20 percent at $\$ 10,000$, and by 10 to 14 percent between $\$ 15,000$ and $\$ 100,000$. Method B would also reduce the tax by 100 percent at $\$ 5,000$, but at higher levels the new tax would be very close to the tax under present law, with a range of +4 percent to -2 percent. In other words, if the revenue raised as a result of the built-in flexibility of the individual income tax during an inflation were distributed in accordance with taxable incomes corrected for the inflation (roughly method B), the major beneficiaries would be the taxpayers with the lowest incomes. The tax liabilities of taxpayers with higher incomes would not be altered significantly. Since the inflation assumed for purposes of the illustrations in Table 8 greatly exceeds the inflations experienced in the United States, the only adjustment that seems to be needed is a periodic adjustment of the exemptions (without changing the rate brackets) in order to eliminate the inflation penalty for those who are at or near the minimum taxable levels.

\section{Summary and Implications}

Despite frequent changes in the tax law, annual individual income tax liabilities during the last twenty-five years can be estimated within relatively small margins of error on the basis of two simple regressions. The first relates taxable income to personal income per capita and exemptions per capita, and the second calculates tax liabilities by multiplying taxable income by a rate variable representing the average tax rate on taxable income. Beginning in 1964, an additional taxable income variable is needed in the tax liability equation to track the rise in the average effective tax rate, which undoubtedly has been a response to the movement of taxable incomes upward in the rate brackets as per capita income has increased. In 1971, the last year for which the official Statistics of Income are available, the built-in flexibility measure derived from these equations suggests that the individual income tax increased by about $\$ 1.6$ billion when adjusted personal income increased by $\$ 10$ billion, and the elasticity measure suggests that individual income tax revenues rose about 14 percent when adjusted personal income rose 10 percent.

The regression analysis explains past movements in income tax liabilities 
remarkably well. However, it gives lower estimates than do the tax file simulations for both the built-in flexibility and the elasticity of the income tax under conditions of sustained growth, during the contraction phase of a business cycle, and during periods of inflation. The reason is that the variable that was intended to take the effect of progression into account measures only the effect of what happened in the past; it cannot predict the effects of progression after the absolute distribution of income has shifted substantially upward. The prediction errors become larger, of course, as the period of projection is lengthened. Thus, the income tax equation in econometric models, which is usually based on recent experience and modified only for statutory changes, gives satisfactory results for brief periods in which incomes continue to grow moderately, and becomes increasingly inadequate as the forecast horizon is extended or if income growth changes abruptly in response to either a business contraction or an inflationary shock. In such circumstances, projections on the basis of the tax file will give better results.

The federal individual income tax continues to be an effective built-in stabilizer to the extent that the economic behavior of individuals depends on their disposable income computed on an after-tax liability basis. Although tax rates have been reduced and exemptions and personal deductions have been liberalized, the built-in flexibility and elasticity of the income tax are already higher now than they were during the 1950s and early 1960s. With present rates and exemptions, assuming per capita income growth of 5 or 6 percent a year, individual income tax revenues would increase by about $\$ 1.8$ billion for every $\$ 10$ billion increase in adjusted personal income in 1975 and by about $\$ 2.0$ billion in 1980. In the type of brief and mild contractions experienced in the United States since the end of World War II, the automatic responsiveness of the income tax would be even higher because exemptions continue to increase when incomes decline and thus reinforce the effect of progression. ${ }^{42}$

42. These conclusions apply to the individual income tax only on a liability basis. The national accounts data, which are the basis for most of the econometric work on the stability of the economy, are on a payments basis. Since legislative changes in withholding rates may cause large changes in year-end settlements, seasonally adjusted individual income tax payments are frequently discontinuous in the first quarters of years in which refunds increase or decrease sharply. For example, individual income tax refunds rose from about \$14 billion in early 1972 to about \$22 billion in early 1973. As a result, federal individual tax payments, as measured in the national accounts, fell at an annual rate of $\$ 2.8$ billion in the first quarter of 1973, a quarter in which adjusted personal income rose by $\$ 25.1$ billion. On a liability basis, the individual income tax proba- 
The responsiveness of the income tax to changes in money incomes other than capital gains is roughly the same whether the changes reflect increases in real income solely or include substantial price effects as well. Experiments with the tax file suggest that changes in the distribution of adjusted personal income (which does not include capital gains) of the type experienced during the past twenty-five years have virtually no effect on built-in flexibility or elasticity.

The only circumstance in which changes in the distribution of income do have a significant effect is when capital gains rise or fall sharply relative to other incomes. Recent fluctuations in reported capital gains have been very large. Since they are heavily concentrated in the top income classes, capital gains have major revenue consequences even though they are subject to a top rate of 36.5 percent. Furthermore, if stock market movements are erratic or if they do not correspond closely with movements in general business activity, capital gains can have a perverse effect on the built-in flexibility of the income tax.

During periods of inflation, there is an automatic transfer of real resources from the taxpayer to the government as a result of the progressivity of the income tax. Surprisingly, the transfer is not very large in the aggregate-and does not vary greatly by income classes-even for much more severe inflations than those experienced in the United States in recent years. Periodic adjustments to keep exemptions in line with increases in living costs should be sufficient to eliminate the most burdensome feature of the income tax during periods of rising prices.

bly rose at an annual rate of about $\$ 4$ billion during this quarter. This estimate was obtained by multiplying the $\$ 25.1$ billion increase in adjusted personal income by a builtin flexibility estimate derived from the tax file of 0.17 . Whether the payments or the liability basis is more appropriate for economic analysis is debatable, but the differences clearly are not inconsequential. 


\title{
APPENDIX
}

\section{Derivations of Estimating Equations Based on Time Series}

\author{
ROBERT E. LITAN
}

THIS APPENDIX brings up to date and revises the time series estimates of taxable income $(Z)$ and tax liabilities $(T)$ originally presented in an article by William $\mathrm{H}$. Waldorf. ${ }^{1}$ The revisions are necessary to incorporate the effects of the Revenue Acts of 1964, 1969, and 1971 and of changes in the distribution of income in the specification of two of his equations. The data used in preparing the revised specifications are given in Table A-1.

In his initial equation, Waldorf used the following form, developed by Brown and Kruizenga, to estimate $Z:^{2}$

$$
1-\frac{Z}{Y}=a_{0}\left(\frac{Y}{N}\right)^{a_{1}}\left(\frac{E}{N}\right)^{a_{2}} a_{3} D_{58-65},
$$

where $Y$ is personal income, $N$ is total population, $E$ is personal exemptions, $D$ is a dummy variable, and $a$ represents the respective coefficients. Thus, this equation relates the percentage of nontaxable personal income $(1-Z / Y)$ to per capita personal income $(Y / N)$, per capita exemptions $(E / N)$, and a dummy variable for $1958-65\left(D_{58-65}\right)$. Per capita income is included as an independent variable because rising per capita incomes tend to raise the percentage of income that is subject to tax. Increases in per capita exemptions have the opposite effect. The 1958-65 dummy variable was used to pick up what appeared to be a significant shift in the relationship between taxable and personal income during that period, although Waldorf acknowledged that the dummy improved the fit of the equation only modestly.

1. "Responsiveness of Federal Personal Income Taxes," pp. 37-44.

2. See "Income Sensitivity of a Personal Income Tax" for a detailed discussion of the formulation of this equation. 
The version of equation (1) in logarithmic form for the 1947-65 period is $^{3}$

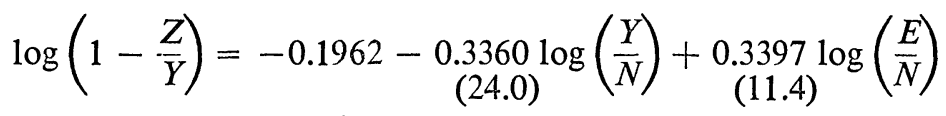

$$
\begin{gathered}
+0.0189 D_{58-65 .} \\
(3.6) \\
\bar{R}^{2}=0.987 ; \text { standard error of estimate }=0.0064 ; \\
\text { Durbin-Watson statistic }=2.37 .
\end{gathered}
$$

Waldorf tried per capita personal deductions and capital gains as explanatory variables, but met with little success. He also found that a better statistical fit was obtained when adjusted gross income was substituted for personal income in (2)-a not unexpected result because most of the items that are subtracted from or added back to personal income to arrive at adjusted gross income are either exogenous or are not directly related to personal income.

Several experiments were conducted in the process of updating this equation to cover the years through 1971. Again, personal deductions per capita did not perform well as an independent variable, and the substitution of adjusted gross income for personal income yielded better results. However, three other changes also improved on Waldorf's specifications.

First, the dummy variable Waldorf used to account for the break in the relationship between taxable and personal income beginning in $1958 \mathrm{can}$ be eliminated if the personal income variable is properly adjusted. Specifically, the 1958 break appears to be due mainly to the large boost in transfer payments in that year. If transfer payments $(P)$ are subtracted and the associated increases in personal contributions for social insurance $(S)$ are added to personal income, an adjusted personal income series $\left(Y_{a}\right)$ substantially free of two major exogenous components can be constructed. This adjusted series, which was used to replace $Y$ in (1), can be explained without a dummy variable for 1958-65; it is also more useful for prediction and simulation purposes (since $Y_{a}$ can be projected more easily than $Y$, and $P$ and $S$ must usually be estimated separately in any case).

Second, one major revision was made on the right-hand side of the equation. Contrary to the evidence presented by Waldorf for 1947-65, capital

3. Some of the coefficients in (2) differ from those originally presented in Waldorf's article (p. 38) because he estimated the equation with logarithms to the base 10 whereas logarithms to the base $e$ are used here. The numbers in parentheses here and in subsequent equations are $t$-statistics. 


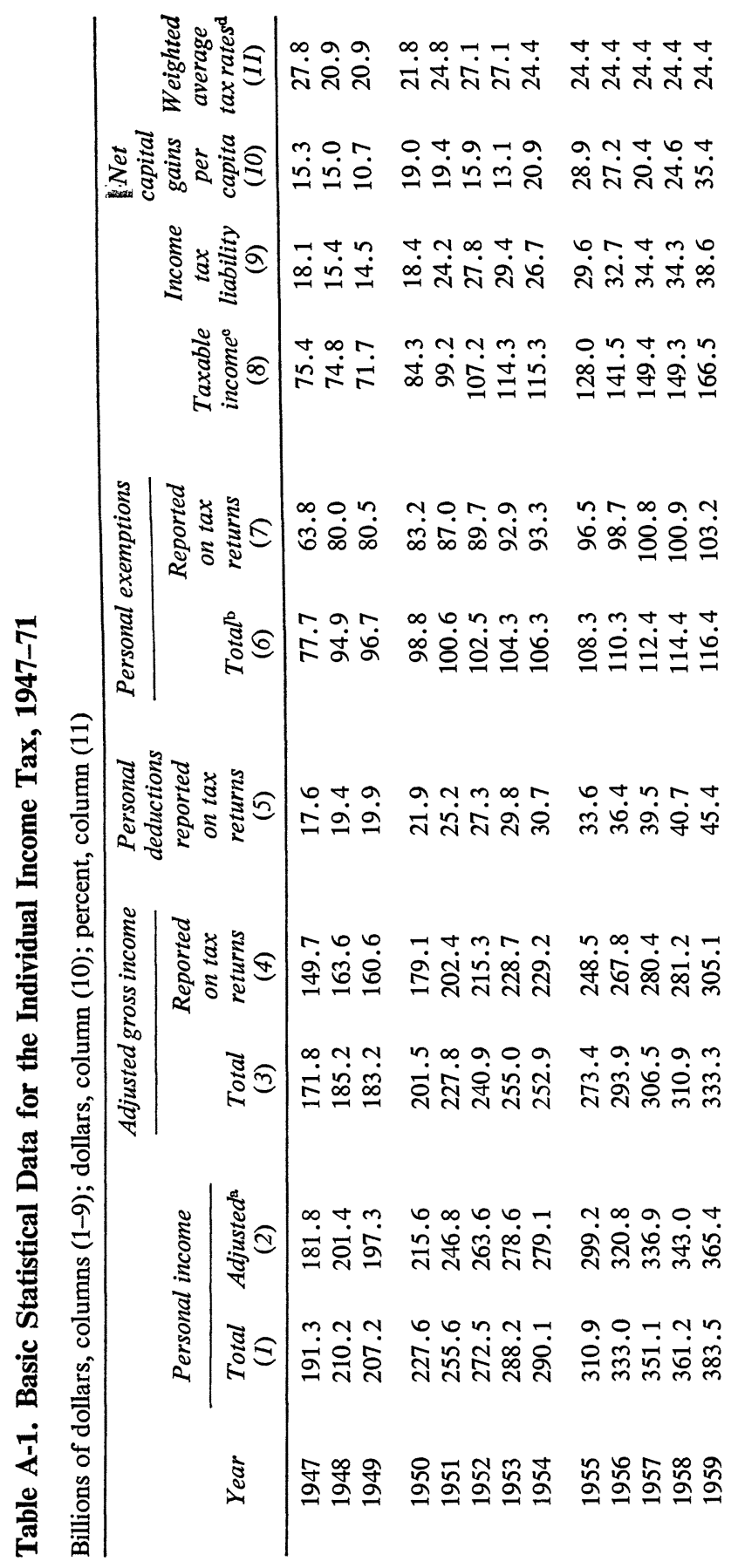




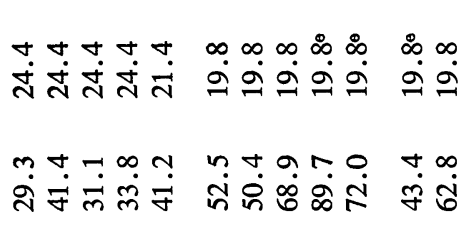

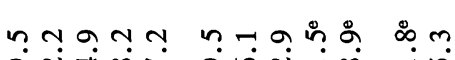

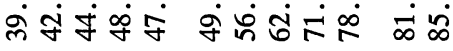

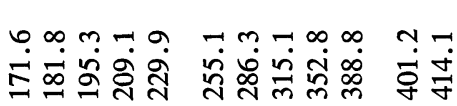

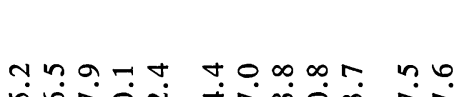

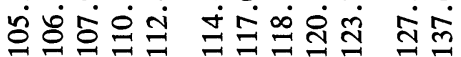

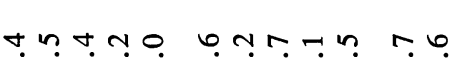

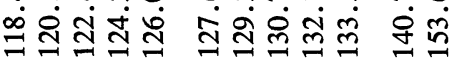

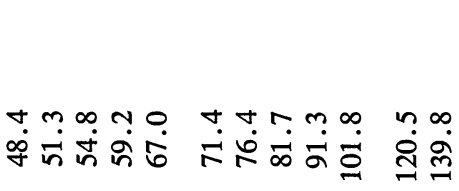

naron rnotn To m

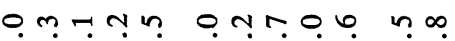

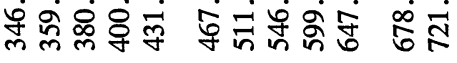

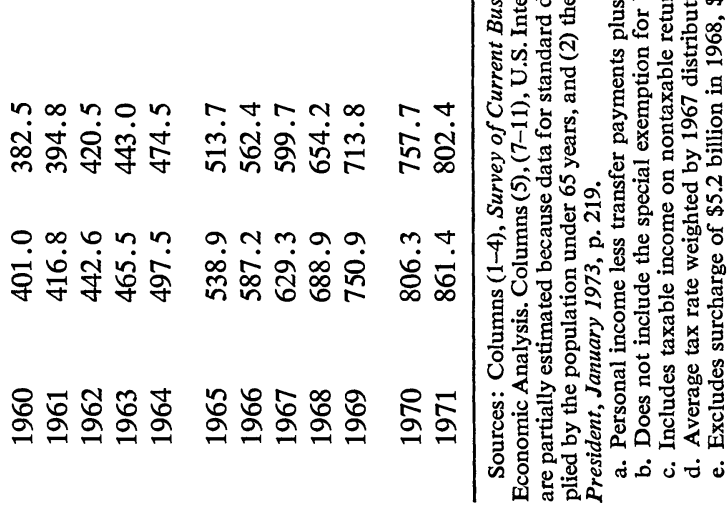


gains per capita $(C / N)$ were found to exert a significant positive effect on the fraction of taxable personal income over the expanded time period. Since capital gains have shown much more volatility since 1965 than they did before, they must be included as an independent variable in the equation. Otherwise, the elasticity of taxable income with respect to adjusted personal income would be overstated.

Third, a dummy is needed for the 1970-71 years $\left(D_{70-71}\right)$ because of the sharp increase in the minimum standard deduction and the introduction of the low-income allowance by the Tax Reform Act of 1969. As an alternative to the dummy variable approach, a per capita estimate of the effect of the new provisions was included in the exemptions series, but this did not improve the statistical performance of the equation.

When estimated in logarithmic form over the 1947-71 years, the revised taxable income equation becomes

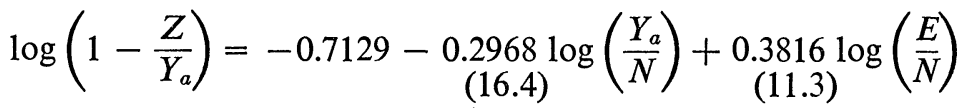

$$
\begin{aligned}
& -\underset{\text { (3.4) }}{0.0289 \log }\left(\frac{C}{N}\right)+\underset{(3.0)}{0.0252 D_{70-71}} \\
& \begin{array}{c}
\bar{R}^{2}=0.994 ; \text { standard error of estimate }=0.0079 ; \\
\text { Durbin-Watson statistic }=1.73 \text {. }
\end{array}
\end{aligned}
$$

Predicted values of taxable income and residuals from equation (3) are presented in Table A-2. Although, in general, the statistical properties of the equation are satisfactory, the serial correlation in the residuals tends to become more pronounced when the predicted values are converted to dollar amounts, as shown in the table, from the ratio form in which they are fitted. The equation overpredicts taxable income slightly, but consistently, between 1960 and 1966, and misses by much larger amounts in 1970 and 1971. Equation (3) was also fitted without the capital gains variable. Although this calculation resulted in a slightly poorer statistical fit, the serial correlation in the errors was less pronounced, and the residuals in 1970 and 1971, in particular, were significantly smaller than those in the equation presented here.

Waldorf's equation for tax liabilities $(T)$ is essentially of the following form:

$$
T=b_{0} r^{b_{1}} Z^{b_{2}}
$$

where $r$ is the tax rate for the first $\$ 2,000$ of taxable income. 
Table A-2. Actual, Predicted, and Simulated Values of Taxable Income and Tax Liabilities, 1954-71

Billions of dollars

\begin{tabular}{|c|c|c|c|c|c|c|c|c|}
\hline \multirow[b]{2}{*}{ Year } & \multicolumn{3}{|c|}{ Taxable income } & \multicolumn{3}{|c|}{ Tax liabilities } & \multicolumn{2}{|c|}{$\begin{array}{c}\text { Tax liabilities } \\
\text { obtained from } \\
\text { taxable income in } \\
\text { equation }(3)\end{array}$} \\
\hline & Actual & Predicted & Residual & Actual & $\begin{array}{c}\text { Pre- } \\
\text { dicted }\end{array}$ & Residual & $\begin{array}{l}\text { Simu- } \\
\text { lated }\end{array}$ & Residual \\
\hline 1954 & 115.3 & 116.1 & -0.8 & 26.7 & 26.7 & 0.0 & 26.8 & -0.1 \\
\hline 1955 & 128.0 & 128.7 & -0.7 & 29.6 & 29.6 & 0.0 & 29.7 & -0.1 \\
\hline 1956 & 141.5 & 140.4 & 1.1 & 32.7 & 32.7 & 0.0 & 32.4 & 0.3 \\
\hline 1957 & 149.4 & 147.5 & 1.9 & 34.4 & 34.5 & -0.1 & 34.1 & 0.3 \\
\hline 1958 & 149.3 & 151.2 & -1.9 & 34.3 & 34.5 & -0.2 & 34.9 & -0.6 \\
\hline 1959 & 166.5 & 166.0 & 0.5 & 38.6 & 38.4 & 0.2 & 38.3 & 0.3 \\
\hline 1960 & 171.6 & 174.4 & -2.8 & 39.5 & 39.6 & -0.1 & 40.2 & -0.7 \\
\hline 1961 & 181.8 & 183.0 & -1.2 & 42.2 & 41.9 & 0.3 & 42.2 & 0.0 \\
\hline 1962 & 195.3 & 196.2 & -0.9 & 44.9 & 45.0 & -0.1 & 45.2 & -0.3 \\
\hline 1963 & 209.1 & 209.9 & -0.8 & 48.2 & 48.2 & 0.0 & 48.4 & -0.2 \\
\hline 1964 & 229.9 & 230.2 & -0.3 & 47.2 & 47.3 & -0.1 & 47.4 & -0.2 \\
\hline 1965 & 255.1 & 256.1 & -1.0 & 49.5 & 49.4 & 0.1 & 49.6 & -0.1 \\
\hline 1966 & 286.3 & 286.6 & -0.3 & 56.1 & 56.2 & -0.1 & 56.3 & -0.2 \\
\hline 1967 & 315.1 & 312.8 & 2.3 & 62.9 & 62.6 & 0.3 & 62.1 & 0.8 \\
\hline 1968 & 352.8 & 350.5 & 2.3 & $71.5^{\mathrm{a}}$ & 71.1 & 0.4 & 70.6 & 0.9 \\
\hline 1969 & 388.8 & 387.8 & 1.0 & $78.9^{a}$ & 79.3 & -0.4 & 79.1 & -0.2 \\
\hline 1970 & 401.2 & 397.1 & 4.1 & $81.8^{a}$ & 82.1 & -0.3 & 81.2 & 0.6 \\
\hline 1971 & 414.1 & 418.5 & -4.4 & 85.3 & 85.1 & 0.2 & 86.1 & -0.8 \\
\hline
\end{tabular}

Sources: Actual, Statistics of Income, Individual Income Tax Returns, for the respective years; other data, equations (3) and (6).

a. Excludes surcharge of $\$ 5.2$ billion in $1968, \$ 7.7$ billion in 1969 , and $\$ 2.0$ billion in 1970 .

As explained in the text, Waldorf needed dummy variables to explain the changes in the tax rates between 1947 and 1963. In addition, to account for the increase in the elasticity of tax liabilities with respect to taxable income induced by the 1964 revenue act, Waldorf estimated tax liabilities in two stages. First, he estimated the equation over the 1947-63 period, obtaining an elasticity of 0.9955 . Second, using the results of simulations from one of the earlier tax files, ${ }^{4}$ he calculated the effective rate of tax on income for the year 1965. Finally, a dummy variable for 1964 was constructed, ex post, to complete the equation.

The Waldorf tax liabilities equation estimated in logarithmic form over the $1947-63$ period is ${ }^{5}$

4. See Pechman, "A New Tax Model for Revenue Estimating."

5. This equation also differs from that presented in Waldorf (p. 9) because it is fitted in terms of logarithms to the base $e$ rather than to the base 10 . 
$\log T-\log r=0.2259+0.9955 \log Z+0.0221 D_{47}$

(5)

$$
+0.0210 D_{50}-0.0262 D_{51}-0.0532 D_{52-53}-0.0254 D_{54-63} \text {. }
$$

$\vec{R}^{2}=0.999 ;$ standard error of estimate $=0.0055$;

Durbin-Watson statistic $=3.03$.

Here, the elasticity of $T$ with respect to $r$ is constrained to unity, thus permitting $r$ to be moved to the left-hand side of the equation.

Although the explanatory power of equation (5) is reasonably good, the residuals are clearly serially correlated. There are also conceptual difficulties associated with the presence of so many dummy variables. The estimates were improved by confining the period of estimation to 1954-71, by substituting a new rate variable for the rate on the first $\$ 2,000$ of taxable income, and by introducing another taxable income variable to account for the rise in the average effective tax rate on taxable income beginning in 1965. The resulting equation, which was fitted in logarithmic form to the data for the years 1954-71, is as follows:

$$
\log T-\log R=-0.7058+0.9950 \log Z+0.1280 \log Z_{a}
$$

$$
\begin{gathered}
+0.6776 D_{54-63 .} \\
(12.5) \\
\bar{R}^{2}=0.999 ; \text { standard error of estimate }=0.0040 ; \\
\text { Durbin-Watson statistic }=2.55 .
\end{gathered}
$$

Here, $R$ is an average tax rate computed by weighting the tax rates for each bracket in any year by the taxable income in that bracket in 1967. This variable, which is a more representative proxy for the tax rate structure, replaces $r$ in (5). The additional taxable income variable, $\log Z \mathrm{t}$, is set at 0 prior to 1964 , but is identical to $\log Z$ thereafter. The dummy for $1954 \mathrm{~B} 63$ is needed to account for the peculiar stability in the effective tax rate during that period.

The residuals from (6) and a related simulation are shown in Table A-2. The equation fits very well, with the largest error, $\$ 0.4$ billion, occurring in both 1968 and 1969. Even when estimated values of $Z$ from equation (3) are used as the independent variable in (6), the tax liability residuals (last column) remain remarkably small.

Equation (6) was also fitted over the 1948-71 period, but was modified by the addition of a dummy variable for 1952B 53 and another taxable in- 
come variable, $\log Z_{b}$, which assumed the value of 0 after 1954 . The dummy was used to account for the unusually low amount of capital gains in 195253. The variable $Z_{b}$ was added to test the hypothesis that the rapid rise in personal incomes between 1948-53 shifted the elasticity of $T$ with respect to $Z$ above 1 . The resulting equation confirmed this hypothesis; in fact, the shift in the elasticity between 1948-53 (0.13) exceeded the shift recorded in 1965-71 (0.10) by 3 percentage points:

$$
\log T-\log R=-0.5712+0.9950 \log Z+0.1047 \log Z_{a}
$$

$$
\begin{gathered}
+0.1310 \log Z_{b}+0.5430 D_{54-63}-0.0688 D_{52-53} . \\
(5.2) \quad(4.6) \quad(6.8) \\
\bar{R}^{2}=0.999 ; \text { standard error of estimate }=0.0095 ; \\
\text { Durbin-Watson statistic }=2.760 .
\end{gathered}
$$

Residuals for this equation exhibited a greater degree of serial correlation than those in (6), but were generally of the same magnitude. Equation (7) was not used for projection purposes, however, since (6) provides a more realistic future estimate of the elasticity of tax liabilities with respect to taxable income. 


\section{Comments and Discussion}

Edward Gramlich: One of the great turnabouts in the past few years is the change in the federal budget from a surplus-prone to a deficit-prone position. Whereas in 1963 fiscal advisers were worried about full employment surpluses, fiscal drag, and finding good uses for the nation's money, in 1973 advisers are worried much more about full employment deficits, inflationary gaps, and finding the money for the nation's uses.

There is, of course, no mystery about what happened. Several tax cuts and a very sharp rise in expenditures, domestic as well as military, have occurred since the fiscal drag days. But the phenomenon that gave rise to the worry about fiscal drag - the income elasticity of the federal tax system -is still important precisely because the nation may want more tax cuts and higher expenditures in the future. The ability to forecast this income elasticity at least a few years in advance is important because the proper timing of these new initiatives is important. And it becomes especially desirable to forecast the elasticity accurately in times, such as the present, when prices and money incomes are rising rapidly.

Pechman's paper handles these questions very competently and completely for the individual income tax, the largest and most difficult tax to forecast. He makes forecasts in two ways-with a two-equation model beginning with personal income explaining taxable income and then tax liabilities, and with a microsimulation of a sample of individual tax returns for 1970. Both the regression and the microsimulation model are extrapolated all the way to 1995 under varying assumptions about the growth of overall money income and certain of its key components.

One of the interesting features of the paper is that it provides a chance to compare the two methods of forecasting. The assumptions underlying the regression forecast are that the structure of both regressions remains the 
same in the forecast period-which is to say that the distribution of personal income is the same as some average over the regression sample, that the propensity to itemize deductions does not shift, and that the increase in the average tax rate due to progressivity is the same as in the period since the 1964 tax cut. In the simulation forecasts the first two of these assumptions are necessary but not the third: the time series effects of rate progressivity can be calculated exactly from the cross section of tax rates for various incomes in 1970.

Pechman finds that the projections of taxable income, and thus of components of income and the propensity to itemize, from forecasts made in these two different ways are rather close. But the projections of tax liabilities based on this taxable income vary enormously: they are $\$ 26$ billion higher in the microsimulation by 1980 if money personal income grows at the not unreasonable annual rate of 8 percent until then. In other words, in just seven years the forecasting difference between using a microsimulation file and a tax liability regression, which are both quite accurate during the sample period, is almost enough to allow us to plan a Vietnam War for 1980 without appreciably altering overall fiscal policy. (Incidentally, the regression method works even better than the simulation file in the three years of the sample period for which Pechman makes comparative forecasts.) To say the least, it is not very reassuring to a forecaster that two methods that give identically accurate past forecasts give wildly divergent forecasts outside of the sample period.

My only complaint with the paper is that this key issue is not discussed as extensively as it should have been. There are several possible reasons for the divergence, but my own prime suspect is the tax liability regression (equation 6 in the appendix). In fitting this equation Pechman and Litan have computed the effective tax rate, $R$, by using the 1967 importance of various taxable income brackets to weight the rates in the various brackets. This technique is much to be preferred to that used by Waldorf, which was simply to use the bottom bracket rate and in effect ignore changes at all other points in the rate scale. And it does fit the past data well. But it still may leave something to be desired when used for forecasting. As income grows over time, more of it will be shifted into the higher-rate brackets, thus raising the weights that should be applied to the higher rates in the scale and average tax rates. Pechman and Litan capture this phenomenon by permitting taxable income to have an elasticity greater than one, which leads to an increase in average tax rates. But if rate progressivity schedules 
are not smooth - and the sharp divergence in projected values of tax liabilities indicates they may not be-the elasticity of taxable income might change beyond the sample period and pose difficulties for the regression forecast. One way to get around the problem is with a Pechman-type microsimulation; another would be to try to work out some scheme for changing the weights in $R$ during the estimation and then the extrapolation period. The latter approach would by no means be easy; indeed, one could say that it just shifts the problem from fitting the regression to finding the way to construct $R$, but there may be some payoff in experimenting with such an approach.

Oswald Brownlee: The economics profession is indebted to Joe Pechman for introducing and gaining acceptance for the kind of simulation used in this paper to estimate the effects of changes in the tax structure on income distribution and tax revenues. This paper demonstrates the tax yield possibilities of the federal individual income tax if its present rate, exemption, and preference structure were to be maintained. By 1995, with an annual growth rate of 4 percent in per capita income, the average marginal tax rate would rise to more than 25 percent. With an average tax rate of about 17 percent, this would yield tremendous revenues-more than $\$ 400$ billion.

Of course, the individual income tax structure is unlikely to remain unchanged. Although I am quite sure that Congress follows no rule that personal income tax should always be aimed at about 10 percent of personal income, it has seen fit to reduce the rates, raise the exemptions, or increase personal deductions as income has risen, so that the average individual income tax collections have remained approximately constant at this level for quite a long time. I expect a comparable course of action in the future. Consequently, Pechman's results should be interpreted-and I believe this is also his interpretation-as the leeway that Congress will have in altering the rate structure, exemptions, and deductions in the future.

Although the built-in flexibilities-the derivatives of total individual income taxes collected with respect to adjusted personal income-increase with income, the elasticities all diminish. Obviously, this is because the average tax rate is rising faster than the marginal rate. If the marginal rate were constant, and the constant of the tax function as it is related to income were negative, the range of positive values for elasticities would begin at plus infinity and converge toward one.

The yield estimates are in nominal terms so that any combination of 
rates of increase in real income and in the price level that add to a given rate of increase in nominal income will provide the corresponding computed yields, weighted marginal rates, and average rates shown in the tables. The tax yield effects of inflation and real income growth are indistinguishable, except on the basis of specific assumptions about changes in the distribution of income (as between wages and profits, in Pechman's example).

I am somewhat perplexed by the suggestion that "if the exemptions and the tax brackets were adjusted to eliminate this real tax increase, the revenue lost could be recovered by increasing the tax rates by an average of 3.1 percentage points in each bracket." I thought that the objective of adjusting rates and exemptions to account for the inflation was to make the real tax take depend upon real income and thus be invariant with respect to the inflation rate. In fact, if rates were increased by the same percentage in each bracket and the increase restored the government's revenue loss, the two adjustments would approximately cancel each other for every taxpayer.

I do not believe that the implication that higher marginal tax rates result in greater stability in the behavior of income with respect to certain exogenous shocks is correct. It is true that the static multiplier of income with respect to an exogenous expenditure change generally is smaller with higher marginal tax rates than it is with lower ones, but the actual variance in the movement of income over time may be larger with higher values for the built-in stabilizer than with lower values. Obviously, if the correlation between the disturbance and the so-called stabilizer is small, as would be the case if the period of the disturbance is shorter than the time required for taxes to react to income, the variance-minimizing marginal tax rate could be zero.

\section{General Discussion}

The issues of inflation and built-in stability elicited comments from several of the conference members. Robert J. Gordon noted that economic and demographic groups are affected differently by inflation and real income growth, although the tax revenues generated by the two processes may be the same. Whereas growth in real income tends to increase average 
effective tax rates fairly uniformly, inflation imposes uneven tax increases which depend upon the sources of personal income and wealth. Gordon referred to homeowners with prenegotiated mortgages as an example of individuals who are trapped into effective tax increases because they cannot alter their behavior rapidly enough. In response, Pechman said that he had been interested primarily in the effects of inflation on different income levels. He remarked that the tax file could be used to study the impact of inflation on different demographic groups.

George Perry noted that it was incorrect to view the automatic revenue increase coming from inflation as another aspect of the U.S. tax system as an automatic stabilizer. The built-in flexibility of the tax with respect to cyclical variations in real incomes acts as an automatic stabilizer because it works both ways: it supports income when the economy falls below the trend line and restricts it when the economy rises above trend. Thus, it dampens cyclical variations in real incomes. But the built-in flexibility of the tax with respect to inflation is asymmetrical. Tax revenues increase as prices rise in an inflation but they do not fall correspondingly when inflation ends-except in the unlikely event that prices fall to their original level. As a result, the response of revenues to inflation makes for a permanent transfer of income to the public sector which must be followed by a discretionary reduction in tax rates if the same real tax level is to obtain after inflation has subsided.

Several participants expanded on Gramlich's comments on the specification of the regression model. Lawrence Klein argued that the $R$ variable should have been specified differently. He thought that the regression model had performed well over the sample period because the first rate bracket had been dominant, as was the case in the Brown-Kruizenga paper. But for the future, a specification that allowed $R$ to vary with income distribution could be expected to predict better.

Charles Holt and Stephen Goldfeld asked whether Pechman had considered combining the tax and the regression models. Holt suggested that it would be possible to use data from the tax bank about different exemption levels, rules about deductions, and similar variables to generate predictions from the tax model about tax collections at different rates and income levels. These predictions could then be put into a regression model in order to estimate the effects of such things as rate changes. Goldfeld asked whether it would not be possible to translate the tax file's adjustments for changes in income tax, inflation, the rate of economic growth, and other 
relevant variables into simple changes in the variables of such a regression equation. The regression model would approximate the structural characteristics obtainable from the tax file but would be easier to use. Pechman answered that a simple formula could probably be developed, and agreed that the type of analysis suggested by Holt and Goldfeld would be worthwhile. He noted that this kind of analysis might be similar to respecifying $R$ in a more complex way, as Gramlich and Klein had suggested, and would bring the regression projections closer to those obtainable with the tax file.

Thomas Juster noted that the specific behavior that determined the relation of deductions to income was hard to project. The growth of homeownership, for example, was the single most important factor behind the growth of deductions. He added that it could be difficult to include explicitly in a forecasting model the complex of forces that affect itemizing behavior, and that any assumption about it-such as Pechman's assumption that deductions have an elasticity of 1.05 with respect to income - could not be considered very reliable.

Murray Weidenbaum noted the importance of pursuing Pechman's analysis to generate revenue estimates. He added that the second stage of analysis, estimating tax withholdings, should be relatively easy; estimating personal tax liabilities, which Pechman does, is usually the greatest source of error and surprise in revenue estimating. 